\title{
Erken çocukluk döneminde iki dilliliğin çocukların alıcı ve ifade edici dil gelişimine etkisinin incelenmesi ${ }^{*}$
}

\author{
Investigation of the effects of bilingualism on the development of \\ receptive and expressive language in children in early childhood
}

\begin{abstract}
Murat Özpolat ${ }^{1}$, Mehmet Sağlam²
Makale Geçmişi

Geliş : 1 Temmuz 2020

Düzeltme : 7 Eylül 2020

Kabul : 3 Ekim 2020

Makale Türü

Arastrma Makalesi

Öz: Bu araştırmada erken çocukluk döneminde iki dilliliğin çocukların alıcı ve ifade edici dil gelişimine etkisinin incelenmesi hedeflenmiștir. Araștırma Adıyaman ilinde 2-7 yaş aralı̆̆ındaki iki dilli ve tek dilli $120(60+60)$ çocuk ile yürütülmüştür. Veri toplamada, kişisel bilgi formu ve Türkçe Erken Dil Gelişim Testi (TEDIL) kullanılmıştır. Araştırmadan elde edilen verilerin analizi için uygun istatistik program kullanılmış, elde edilen veriler Kolmogorov-Smirnov testi, t testi, Tukey, ANOVA ve Ki-kare testi kullanılarak analiz edilip değerlendirilmiştir. Araştırma sonucunda; iki dilli ve tek dilli çocukların alıcı ve ifade edici dil becerileri karşılaştırılmış ve gruplar arasında istatistiksel olarak anlamlı fark olmadığı sonucuna ulaşılmıştır. Araştırmada her iki grubun dil gelişimlerine etki edebilecek diğer faktörler de ele alınmıştır. Bu faktörlerden; yaş, cinsiyet, baba eğitim düzeyi, kardeş sayısı, kardeşler arasındaki sıra sayısı, okul durumu, kitap okuma sıklığı, ekran kullanım süresi açısından anlamlı fark bulunmazken, çocukların yaşadığı yer, anne eğitim durumu, anne ve baba mesleği, aile yapısı, çocukla kitap okuma sıklığı, ekran kullanma yaşı ve ekranı kiminle kullandığı değişkenleri açısından iki dilli çocuklar lehine anlamlı fark oluştuğu belirlenmiştir.
\end{abstract}

Article History

Received : 1 July 2020

Revised : 7 September 2020

Accepted : 3 October 2020

Article Type

Research Article
Anahtar Kelimeler: Iki dillilik, Dil gelişimi, Alıcı dil, İfade edici dil

Abstract: The aim of this study was to investigate the effect of bilingualism on the development of receptive and expressive language in early childhood. The research was carried out with $120(60+60)$ bilingual and monolingual children between the ages of 2-7 in Adiyaman province. Personal information form and Turkish Early Language Development Test (TEDIL) were used for data collection. Appropriate statistic program was used for the analysis of the data obtained from the study. The obtained data were analyzed and evaluated using Kolmogorov-Smirnov test, t test, Tukey, ANOVA and chi-square test. As a result of the research; Receptive and expressive language skills of bilingual and monolingual children compared and it was no statistically significant difference between the groups. In the research, other factors that may affect the language development of both groups were also discussed. Of this factors; while there was no significant difference in terms of age, gender, father education level, number of rows between siblings, school status, frequency of reading books, screen usage time; it was determined that there was a significant difference between in favor of bilingual children in terms of the place where the education level of the mother, the occupation of the mother and father, the family structure, the frequency of reading books with the child, the age of using the screen and who used the screen.

Key Words: Bilingualism, Language development, Receiver language, Expressive language

DOI: $10.24130 /$ eccd-jecs.1967202043282

\footnotetext{
* Bu çalışma "Erken çocukluk döneminde iki dilliliğin çocukların alıcı ve ifade edici dil gelişimine etkisinin incelenmesi” adlı yayımlanmış yüksek lisans tezinden (624543) üretilmiştir.

1 Osmaniye Korkut Ata Üniversitesi, Osmaniye Meslek Yüksekokulu, Çocuk Bakımı ve Gençlik Hizmetleri Bölümü, murat.ozpolat2@gmail.com, ORCID: https://orcid.org/0000-0002-7917-6345

2 İnönü Üniversitesi, Sağlık Bilimleri Fakültesi, Çocuk Gelişimi Bölümü, pdgsaglam@gmail.com, ORCID: https://orcid.org/0000-0003-1784-4472
} 


\section{SUMMARY}

\section{Introduction}

Language acquisition is an important process in early childhood. In this period, the child may be exposed to another language or languages other than the language used in the family. The effects of a second language acquisition on the child are still controversial. In this study, the effect of bilingualism on development of receptive and expressive language of children in early childhood was investigated.

\section{Method}

The causal comparative research method, one of the quantitative research methods, was used in the study. The sample of the study consisted of 120 bilingual $(n=60)$ and monolingual $(n=60)$ children aged between 2-7 years residing in the city center and villages of Adiyaman province. Purposeful sampling method was preferred for sample selection. Personal information form and Test of Early Language Development in Turkish (TEDIL) were used for data collection. An appropriate statistical program was used to analyze the data obtained from the study, and the data obtained were analyzed and evaluated using the KolmogorovSmirnov test, $\mathrm{t}$ test, Tukey, ANOVA and Chi-square test. When the socio-demographic characteristics of the children participating in the study were examined, $45.5 \%$ of the girls were monolingual and $54.5 \%$ were bilingual; $55.6 \%$ of men were monolingual and $44.4 \%$ were bilingual. $13.3 \%$ of monolingual users were included in the group of 24-36 months, 20.0\% 36-48 months, 20.0\% 48-60 months, 33.3\% 60-72 months, and $13.3 \% 72-84$ months; $11.7 \%$ of bilingual ones were included in the group of $24-36$ months, $6.7 \% 36$ 48 months, $23.3 \%$ 48-60 months, $35.0 \%$ 60-72 months, and 23.3\% $72-84$ months.

\section{Results}

There was no significant difference in terms of children's age, gender, father's education level, number of siblings, order between siblings, school status, frequency of reading books, and screen usage time; whereas, A statistically significant difference was found between the residence place of the children, mother's education level, parents' profession, family structure, frequency of reading book with child, screen usage age, and people with whom they used the screen. As a result of the study, receptive language and expressive language skills of bilingual and monolingual children were compared and it was concluded that there was no statistically significant difference between the two groups.

\section{Conclusion and Discussion}

The distribution of the receptive language parts of the groups was examined and it was determined that the receptive language parts of those using one language and two languages were similar. When the expressive language parts of the groups were also examined, it was seen that the groups were similar, and the use of two languages or single language did not make a significant difference on the expressive language parts. When the verbal language performance of the groups was examined, a statistically significant difference was found due to the bilingual group. Tulu (2009), in his study, examined the factors affecting the language development of bilingual and monolingual children and stated that monolingual children had higher scores in the Peabody language test than bilingual ones. In her study, Şeker (2010), investigated whether or not foreign language acquisition contributes to children's language development in preschool period. Language 
Processing Test (Language Usage Scale) adapted to Turkish by Layza Eskinazi was used in the study and it was aimed to measure the language usage skills of 6 year-old children with and without preschool education. As a result of the study, it was stated that the children who received foreign language education in all subscales obtained significantly higher scores. Canan (2012), in the study entitled "The Effect of Bilingualism on the Development of Mind Theory in Preschool Children", examined the language development levels of bilingual and monolingual children and found no significant difference between the TEDIL scores of the children. However, a significant difference was found between the bilingual and monolingual children 'mental theory development scores included in the study in favor of bilingual children. In his study, Koşan (2015) stated that the language spoken frequently at home made a significant difference in school readiness of bilingual children receiving and not receiving pre-school education and this difference was only in favor of Turkish speakers at home.

\section{GİRİŞ}

Dil, duygu, düşünce, bilgi, tutum, inanç ve değerleri, kültürü öğrenme ve aktarma gibi işlevleri gerçekleştirmede kullandığımız etkili bir iletişim aracıdır (Doğan, 2017). Ünlü Dil bilimci Ferdinand de Saussure, dili, işaretler ve göstergelerden oluşan bir sistem olarak tanımlamıştır (Köktürk ve Eyri, 2013). N. Chomsky' e göre birey, sezgisel olarak bir ana dili bilgisi ile doğar ve bu bilgi bireyde fark edilmese de mevcuttur. Hangi dilsel topluluk olursa olsun tüm insanlar, beyinlerinde doğuştan bir dil bilgisel sisteme sahiptirler (Koşan, 2015).

Çocuklar, dili öğrenmek için gerekli ilkeleri, bilgileri, sözcükleri ve kalıpları erken çocukluk döneminde kazanmaktadır. Çocuklar konuşmayı başkalarından duydukları seslere uyma ve taklidin yanı sıra, sözcüklerin ihtiyacı olan anlamlarını anlamayla öğrenirler (Yavuzer, 2016). Dilin kazanımı kelimelerin, sayıların, sembollerin kazanılmas1, saklanması ve dil kurallarına uygun olarak kullanılmasının gelişimi şeklinde tanımlanmaktadır. Çocuklar için yeni bir şeyler öğrenmek her zaman zor olmuştur. Dilin kazanımı da çok kolay olmamaktadır. İstek ve ihtiyaçlarını ağlayarak anlatmaya çalışan çocuk, dil kazanımı yoluyla dünyayı keşfetmeye başlamakta ve ne istediğini ses ve semboller yoluyla kolayca anlatabilmektedir (Erdoğan ve ark., 2005). Bu semboller nesne ve olayların geçici temsilcileri ve kavramların parçası olup, kültürden kültüre farklılık göstermektedir (Sağlam, 2015).

İnsanlar dili, önce aile bireylerinden sonra yakın çevresinden edinir. Çevre gelişip genişledikçe dil de gelişir. Genişleyen bu çevrede farklı bir dil kullanımı mevcut ise çocuk da bu ikinci dili edinecek ve kullanacaktır (Tulu, 2009). Gelişim süreci içerisinde bireyler ana dilin yanı sıra birden fazla dil ve dil kuralları ile karşılaşmaktadırlar (Canan, 2012). Bu durumda iki veya çok dillilik kavramları ortaya 
çıkmaktadır. İki dillilik (bilingualism), iki farklı dilde iletişim kurabilme becerisidir. Çocuğun iki dilli olabilmesi için, her iki dili de etkin kullanabilmesi ve kendini ifade edebilmesi gerekir (Doğan, 2017). Morris (2002), çift dilli çocukların, dil kazanımında farklı bir yol izlemekte olduğunu ve öğrendikleri dillerin hem fonetiğini hem kullanım bilgisini hem de anlam bilgisini kazandıklarını belirtmiştir. Bunu yaparken diller arası aktarma kuramına göre bu diller birbirini destekleyerek ilerlemektedir (Aktr. Canan, 2012).

Erken çocukluk dönemi, gelişim alanlarındaki değişimin oldukça hızlı ve etkili olduğu bir dönemdir. Özellikle dil bilişsel gelişimin büyük oranda tamamlandığı bu dönem sosyal bir varlık olan çocuğun anlama, kavrama ve ifade edebilme becerilerini edindiği ve bu becerileri etkin kullanmaya başladığ1 göz ardı edilmemelidir. Bundan dolayı okulöncesi dönemdeki deneyim ve verilen eğitim çocuğun tüm hayatını etkilemektedir. Yaşamın ilk 6 yllını kapsayan bu dönem çocuğun tüm gelişim alanlarının desteklenmesini gerektiren önemli bir dönemdir (Temiz, 2002; Kol, 2011).

Dünya genelinde konuşulan diller üzerine kapsamlı çalışmalar yapan ethnologue.com (url:1)'un Türkiye'de kullanılan diller raporuna göre (Karslı, 2015), 2016 yılında kullanılan dil sayısının 39 olduğu belirtilmiştir (url:1). İki dillilerin tek dillilere göre daha ileri olduklarının en önemli özelliklerinden biri olan bilişsel esneklik birçok araştırma tarafından ortaya konulmuştur. Karslı (2015), tarafından yapılan "Bilişsel Esneklik, İki Dillilik ve Üstbilişsel Kararlar Arasındaki Gelişimsel Bağlantılar” adlı çalışmasında, iki dilli ve tek dilli çocukların üstbilişsel kararların doğruluğu ve bilişsel esneklik düzeyleri incelenmiş olup çalışmaya dahil edilen çocukların bilişsel esneklik seviyelerinde üstbilişsel kararların doğruluğunun düzenleyici rolü irdelenmiştir. Çalışma sonucunda iki dilli çocukların bilişsel esneklik düzeyleri ve üstbilişsel kararların doğruluğu açısından tek dilli çocuklardan daha yüksek performans gösterdikleri belirlenmiştir. Yazıcı ve arkadaşlarının (2010), yaptıkları araştırmada Antalya'da yaşayan 5-6 yaş arası iki dilli çocuklar incelenmiş ve deney grubundaki iki dilli çocukların Türkçe alıcı dil (Peabody Picture Vocabulary Test -PPVT), ifade edici dil (Descoeudres Dictionary Test-DDT) ve ortalama sözce uzunluğu (Language FocusedCurriculumforthePreschool-LFC) düzeylerinin kontrol grubundaki çocuklardan daha yüksek olduğu saptanmıştır. Byers-Heinlein ve arkadaşlarının (2013), yaptıkları “Tek Dilli ve İki Dilli Bebeklerde İlişkisel Kelime Öğrenmenin Gelişimi” isimli çalışmada erken iki dilli deneyimin, ilişkisel kelime öğrenmenin gelişimsel yönünü etkileyip etkilemediğini araştırmıştır. Çalışma sonuçları erken iki dilli deneyimin kelime-nesne ilişkilerini kurmadaki temel becerilerin gelişimini engellemediğini, aksine bu işleyişin farklı erken dil ortamlarında güçlü olduğunu ortaya koymuştur. $\mathrm{Bu}$ araştırma iki dilli ve tek dilli çocukların alıcı ve ifade edici dil gelişim düzeylerinin belirlenmesi ve bu bağlamda karşılaştırılmasını amaçlamaktadır. 


\section{Araştırmanın Amacı}

$\mathrm{Bu}$ araştırmada erken çocukluk döneminde iki dilliliğin çocukların alıcı ve ifade edici dil gelişimine etkisinin incelenmesi hedeflenmiştir.

\section{Alt Amaçlar}

Çalışmada temel amaç iki dilliliğin çocuklarda alıcı ve ifade edici dil gelişimi üzerindeki etkilerinin belirlemektir. Araştırma kapsamında Türkçe Erken Dil Gelişim Testi (TEDİL) aracı kullanılacaktır. TEDİL aracı ile iki dilli ve tek dilli çocukların;

- İki dilli çocukların alıcı dil becerileri ne düzeydedir?

- İki dilli çocukların ifade edici dil becerileri ne düzeydedir?

- Tek dilli çocukların alıcı dil becerileri ne düzeydedir?

- Tek dilli çocukların ifade edici dil becerileri ne düzeydedir?

- İki dilli ve tek dilli çocukların dil gelişimleri alıcı dil becerileri yönüyle farklılık göstermekte midir?

- İki dilli ve tek dilli çocukların dil gelişimleri ifade edici dil becerileri yönüyle farklılık göstermekte midir?

- İki dilli ve tek dilli çocukların dil gelişimlerini ailelerinin demografik özellikleri yönüyle farklılık göstermekte midir?

- İki dilli ve tek dilli çocukların dil gelişimlerinin ekran kullanımları yönüyle farklılık göstermekte midir?

\section{MATERYAL VE METOD}

Bu çalışma erken çocukluk döneminde iki dilliliğin çocukların alıcı ve ifade edici dil gelişimine etkisinin incelenmesi amacı ile gerçekleştirilmiştir.

\section{Araştırmanın Türü}

Çalışmada nicel araştırma yöntemlerinden nedensel karşılaştırma araştırması yöntemi kullanılmıştır. Nedensel karşılaştırma, var olan bir durumun veya olayın sebeplerini, bu sebepleri etkileyen değişkenleri veya bir etkinin sonuçlarını belirlemeye yönelik araştırma türüdür (Büyüköztürk, 2014). 


\section{Araştırmanın Yapıldığı Yer ve Zaman}

Bu çalışma 26.06.2018-15.04.2019 tarihleri arasında Adıyaman ili merkez ve bağlı köylerde bulunan iki dil kullanan (n: 60) ve tek dil kullanan (n: 60) 120 çocuk ile ikamet yerlerinde uygun fiziki ortamlarda yapılmıştır.

\section{Araştırmanın Evren ve Örneklemi}

Araştırmada çalışma grubunu belirlemek için yapılan güç analizinde; örneklem büyüklüğü 0,95 güven aralığında, $\% 5$ yanılg1 düzeyinde ve $\% 80$ evreni temsil etme gücü ile yapılan hesaplamalarda her bir grup için en az 59 kişi olarak belirlenmiştir. Bu doğrultuda Adıyaman ili merkez ve bağlı köylerinde yaşayan 2-7 yaş arasındaki iki dilli (60), tek dilli (60) toplam 120 çocuk ile yapılmıştır. Örneklem seçiminde amaçlı örnekleme yöntemi tercih edilmiştir. Derinlemesine araştırmalarda çalışmacı, amacı doğrultusunda zengin durumları seçebilmek için amaçlı örneklemi tercih eder. Amaçlı örneklemenin türlerinden benzeşik örnekleme bu çalışmada örneklemin belirlenmesinde kullanılmıştır. Benzeşik örnekleme, örneklemin çalışmanın amacı doğrultusunda evrende yer alan benzeşik bir alt grup ya da durumdan oluşturulmasıdır (Büyüköztürk, 2014). Araştırmada iki dilli grubun belirlenmesinde çocuğun aile içinde veya yakın çevresinde çocukla iki dilde iletişim kurulması esas alınırken, tek dilli grubun belirlenmesinde çocuk ile aile ve yakın çevresindeki kişilerin çocuk ile tek dilde (yalnızca Türkçe) iletişim kurması esas alınmıştır. Örneklem seçiminde grupların benzer sosyo-kültürel özellikler taşımasına ve herhangi bir engel durumlarının olmamasına dikkat edilmiştir.

Araştırmaya katılan iki dilli ve tek dilli çocukların yaş ve cinsiyet dağ̣lımları tablo 1 de gösteriliştir. Tablo 1 incelendiğinde araştırmaya dâhil edilen çocukların yaş ve cinsiyet yönünden benzerlik gösterdiği görülmektedir.

Tablo 1. Tek dil ve iki dil kullananlarm cinsiyet ve yass dağglmmlarmmn ki-kare testi sonuclan

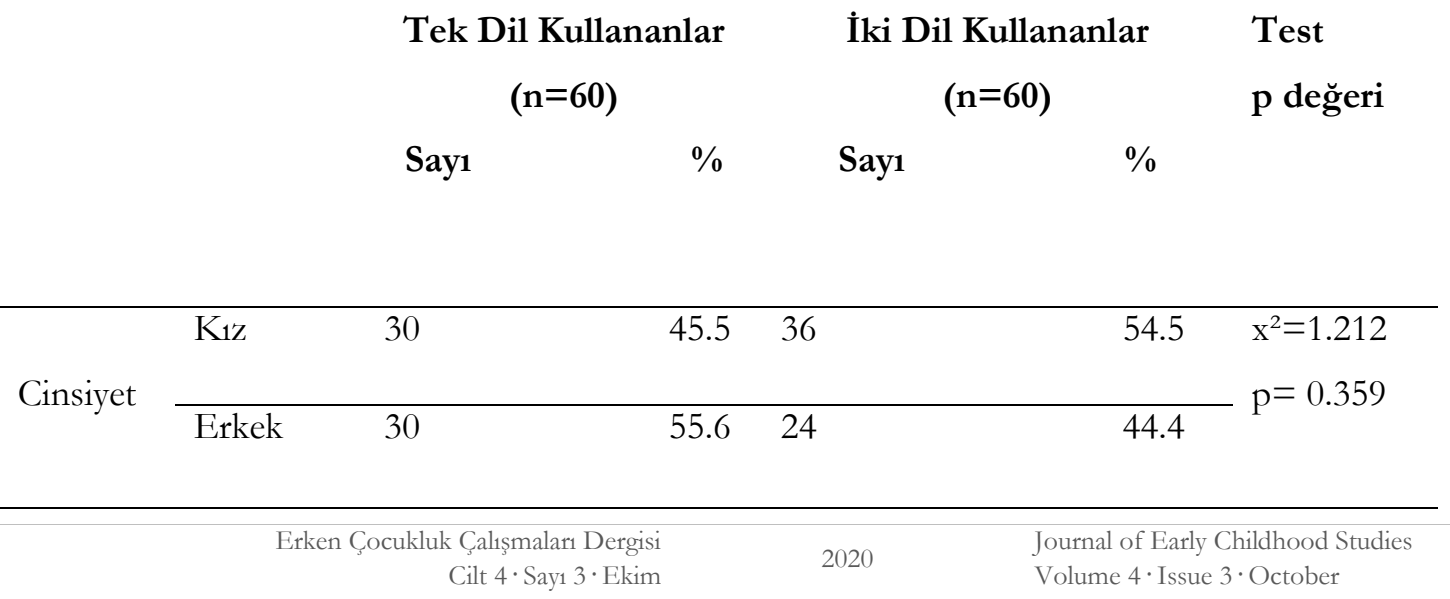




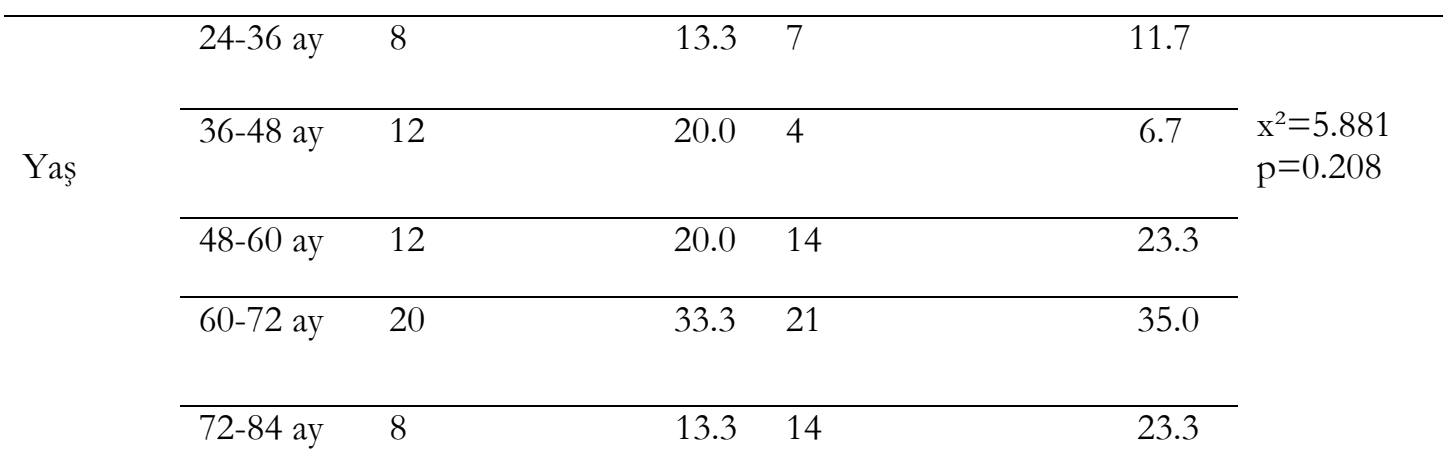

Tek ve iki dil kullananların cinsiyet dağglımları incelenmiş, kızların \%45,5’i tek dil, \%54,5’ i ise iki dil; erkeklerin \%55,6'sı tek dil, \%44,4'ü ise iki dil kullanmaktadır. Yapılan ki-kare analizi sonucunda cinsiyetler arasında anlamlı bir farkll1ık olmadığı görülmüştür $\left(\mathrm{x}^{2}=1.212, \mathrm{p}=0.359\right)$.

Tek dil kullananların yaş ortalaması $\square=54.80 \pm 15.83$, iki dil kullananların yaş ortalaması $\square=60.48 \pm 14,74$ olarak bulundu. Tek dil kullananların \%13,3’ü 24-36 ay, \%20,0'si 36-48 ay, \%20,0'si 48-60 ay, \%33,3’ü 60-72 ay, \%13,3’ü 72-84 ay grubunda; iki dil kullananların \%11,7'si 2436 ay, \%6,7’si 36-48 ay, \%23,3’ü 48-60 ay, \%35,0’i 60-72 ay ve \%23,3’ü 72-84 ay grubunda yer almaktadır. Ki-kare testi sonucunda tek dil kullananlar ile iki dil kullananların yaşlarının birbirine benzer olduğu görülmüştür $\left(\mathrm{x}^{2}=5.881, \mathrm{p}=0.208\right)$.

Tablo 1'deki veriler incelendiğinde her iki grup arasında cinsiyet ve yaş açısından istatistiksel olarak anlamlı bir fark olmadığı yani her iki grubun birbirine benzer özellikte olduğu belirlenmiştir.

\section{Araştırmaya Alınma Kriterleri;}

○ Aile içerisinde iki dil konuşulması

○ Çocukların 2-7 yaş aralığında olması

○ Ebeveynlerin çalışmaya katılım konusunda gönüllü olması

- Herhangi bir işitme ve konuşma probleminin olmaması

\section{Araştırmadan Dışlanma Kriterleri;}

○ Belirgin konuşma bozukluğu olması

- Veri toplama araçlarındaki bilgilerin tam olarak doldurulamaması

○ Veri toplama sürecinin herhangi bir aşamasında çalışmadan ayrılmak istenmesi

\section{Araştırmanın Sınırlı1ıkları}

Araştırma Adıyaman ili merkez ve bağlı köylerde ikamet eden 2-7 yaş arasındaki 60 tek dilli ve 60 iki dilli birey ile sinırlıdır.

Araştırma kapsamında iki dil kullanan ailelerin çocuklarında da TEDiL 'in Türkçe uygulanması araştırmanın bir sınırlılığı olarak değerlendirilebilir.

Adıyaman ilinde çocuklar belirlenirken, iki dilli çocuğun yaşadığı yerden tek dilli çocuklarda seçilmeye özen gösterilmiş ve çocuklar ile ailelerinin demografik özelliklerinin benzer olmasına 
dikkat edilmiştir. Araştırmada Türkçe Erken Dil Gelişim Testi (TEDIL) kullanılmış, ikincil bir ölçek kullanılamamıştır. Kullanılan TEDİL ölçeği ile araştırmaya dahil edilen çocukların yalnızca bir dildeki (Türkçe) alıc1 ve ifade edici dil becerileri ölçülmüştür.

\section{Veri Toplama Yöntemi ve Araçları}

Çalışmanın örneklem seçiminde amaçlı örnekleme yöntemi tercih edilmiştir. Amaçlı örneklemenin türlerinden benzeşik örnekleme bu çalısmada örneklemin belirlenmesinde kullanılmıştır. Araştırmada iki dilli grubun belirlenmesinde çocuğun aile içinde veya yakın çevresinde çocukla iki dilde iletişim kurulması esas alınırken, tek dilli grubun belirlenmesinde çocuk ile aile ve yakın çevresindeki kişilerin çocuk ile tek dilde (yalnızca Türkçe) iletişim kurması esas alınmıştır. Örneklem seçiminde grupların benzer sosyo-kültürel özellikler taşımasına ve herhangi bir engel durumlarının olmamasina dikkat edilmiştir.

\section{Veri Toplama Araçları}

Çalışmanın örneklemini oluşturan çocukların demografik bilgilerini almak için "Erken çocukluk döneminde iki dilliliğin çocukların alıcı ve ifade edici dil gelişimine etkisini belirlemeye yönelik olarak araştırmacı tarafindan oluşturulan "Kişisel Bilgi Formu dil gelişimlerini değerlendirmek için ise "Türkçe Erken Dil Gelişim Testi" (TEDİL) kullanılmıştır. Araştırmaya başlamadan önce Etik Kurul (2018/13-28) izni alınmış ve çalışmaya katılan her bir çocuğun ebeveyni Onam Formu aracılı̆̆1 ile bilgilendirilerek yasal izinleri alınmıştır.

\section{Kişisel Bilgi Formu}

Araştırmacı tarafından hazırlanan "Erken çocukluk döneminde iki dilliliğin çocukların alıcı ve ifade edici dil gelişimine etkisini belirlemeye yönelik kişisel bilgi formu” ile çocukların yaş, cinsiyet, kardeş sayısı, kardeşler arasındaki sıra sayısı, anne ve baba eğitim düzeyleri, anne ve baba meslekleri, aile yapısı, okul ve kreş deneyimi, çocukla kitap okuma sıklığı, çocuğun ekrana maruz kalma süresi ve ekran kullanım şeklini belirlenmeye çalışılmıştır.

\section{Türkçe Erken Dil Gelişim Testi (TEDİL)}

Hresko, Reid ve Hammill (1999) tarafından Amerika Birleşik Devletleri'nde geliştirilen "Test of EarlyLanguge Development-Third Edition (TELD-3)", testi 2 yaş 0 ay ve 7 yaş 11 ay arasındaki çocukların alıcı ve ifade edici sözel dil becerilerini ölçmek amacıyla hazırlanmış, Güven ve Topbaş (2011) tarafından Türkçe’ye uyarlanmıştır. Uluslararası alanyazında Test of Early Language 
Development-Third Edition: TurkishVersion (TELD-3: T) şeklinde tanımlanmış ve Türkçe Erken Dil Gelişimi Testi (TEDİL) adıyla ülkemizde kullanılmaya başlanmıştır (Topbaş ve Güven, 2013).

TEDİL, ile dilin anlambilgisi, biçimbilgisi, sözdizimi, sesbilgisi ve edimbilgisi olarak tanımlanan beş bileşeni test alt maddeleri aracıllğıyla doğrudan ölçülmektedir. TEDİL testi Form A ve Form B olmak üzere iki paralel formdan oluşmaktadır. Kullanmış olduğumuz Form A alıcı dil alt testinde anlambilgisini ölçen 24 madde, dilbilgisini ölçen 13 madde bulunurken; ifade edici dil alt testinde anlambilgisini ölçen 22 madde, dilbilgisini ölçen 17 madde olmak üzere toplam 76 madde bulunmaktadır (Topbaş ve Güven, 2013).

TEDİL ile sözlü dil bileşik standart puanı ve bu puana katkıda bulunan alıcı dil ve ifade edici dil alt testleri puanları ölçülür. Sözlü dil standart puanı, alıcı dil ve ifade edici dil alt test puanlarının birleştirilmesinden elde edilen ve çocuğun tüm sözel dil becerisinin en iyi göstergesidir. Alıcı dil alt testi, çocuğun dili anlama performansını ölçerken, ifade edici dil alt testi çocuğun sözel iletişim becerisini ölçmektedir (Topbaş ve Güven, 2013).

TEDİL alt testlerinin birbiri ile korelasyonu için elde edilen puanlar Pearson r korelasyon katsayıs1 yöntemiyle analiz edilmiştir. Sonuçta alıcı dil ve ifade edici dil alt testleri korelasyon katsayısının 87 ile .90 arasında olduğu, ortanca değerinin .89 olduğu belirtilmiştir. Bu değerler TEDİL alt testlerinin birbirleri ile yüksek bir ilişkiye sahip olduğunu göstermektedir. (Topbaş ve Güven, 2013).

TEDİL'in madde geçerliliği alt testlerinin örneklemin tümünde elde edilen verilerle toplam puanmadde Cronbach Alfa katsayıları Form A alıcı dil alt testi 39 madde için .88, Form B alıcı dil alt testi 37 madde için .90, Form A ifade edici dil alt testi 39 madde için .90, Form B ifade edici dil alt testi 39 madde için .90 olarak çok yüksek bulunmuştur (Topbaş ve Güven, 2013).

TEDİL testi, uzmanlar tarafindan uygulanması gereken bir testtir ve testi uygulayacak uzmanın teste ilişkin formal bir eğitimden geçmiş olması gerekmektedir. Uygulama süresi çocuğun yaş ve becerisi doğrultusunda 15-30 dakika arasında değişebilmektedir (Topbaş ve Güven, 2013).

\section{Verilerin Analizi}

Elde edilen tüm veriler uygun istatistiksel yöntemlerle analiz edilmiştir. Tanımlayıcı istatistikler olarak ortalama, standart sapma, yüzde, medyan ve tepe değeri kullanılmıştır. İncelenen sürekli değişkenlerin normal dağılım parametrelerini karşılayıp karşılamadığı Kolmogorov-Smirnov testi ile değerlendirilmiş, normal dağıldığı tespit edilenlerde bağımsız örneklem t testi, ANOVA ve ki-kare testi kullanılmıştır. İki grup arasındaki farkı saptamak için kullanılan $\mathrm{t}$ testi, birbiriyle ilişkisiz değişken ortalaması arasındaki farkın anlamlı olup olmadığının test edilmesi veya iki grubun bir 
sürekli değişken üzerinden aldıkları değerlerin karşılaştırılmasında kullanılmaktadır (Seçer, 2017). İlişkisiz üç yâda daha fazla düzeyi bulunan bir bağımsız değişkenin, sürekli bir bağımlı değissken üzerindeki etkisini belirlemek için ise ANOVA testi kullanılmıştır. ANOVA tablosunda bulunan değerler için farkın hangi gruplar arasında olduğunu belirlemek için Tukey testi kullanılmıştır (Seçer, 2017). Kategorik değişkenlerin karşılaştırılmasında, ki-kare testi kullanılmıştır. Bu test; iki sınıflamalı (kategorik) değişken arasında anlamlı bir ilişki olup olmadığını test etmek için yapılmaktadır (Büyüköztürk, 2014). Anlamlılık düzeyi .05 ya da altı anlamlı kabul edilmiştir.

\section{BULGULAR}

Erken çocukluk döneminde iki dilliliğin çocukların alıcı ve ifade edici dil gelişimine etkisinin incelenmesi adlı çalışmadan elde edilen bulgular uygun yöntemlerle analiz edilmiş.

Analiz sürecinde tablo $2,3, \ldots 7$ ve 8 'de ki-kare testi, tablo 9, 10, 13 ve 14'te ANOVA, tablo 11'de t testi, tablo 12'de ANOVA ve Tukey testi kullanılmıştır.

Tablo 2. Tek dil ve iki dil kullananlarn yaşadĭg yer, anne ve baba eğitim durumlar, anne ve baba meslek durumlar dağllımlarmm ki-kare testi sonuclan

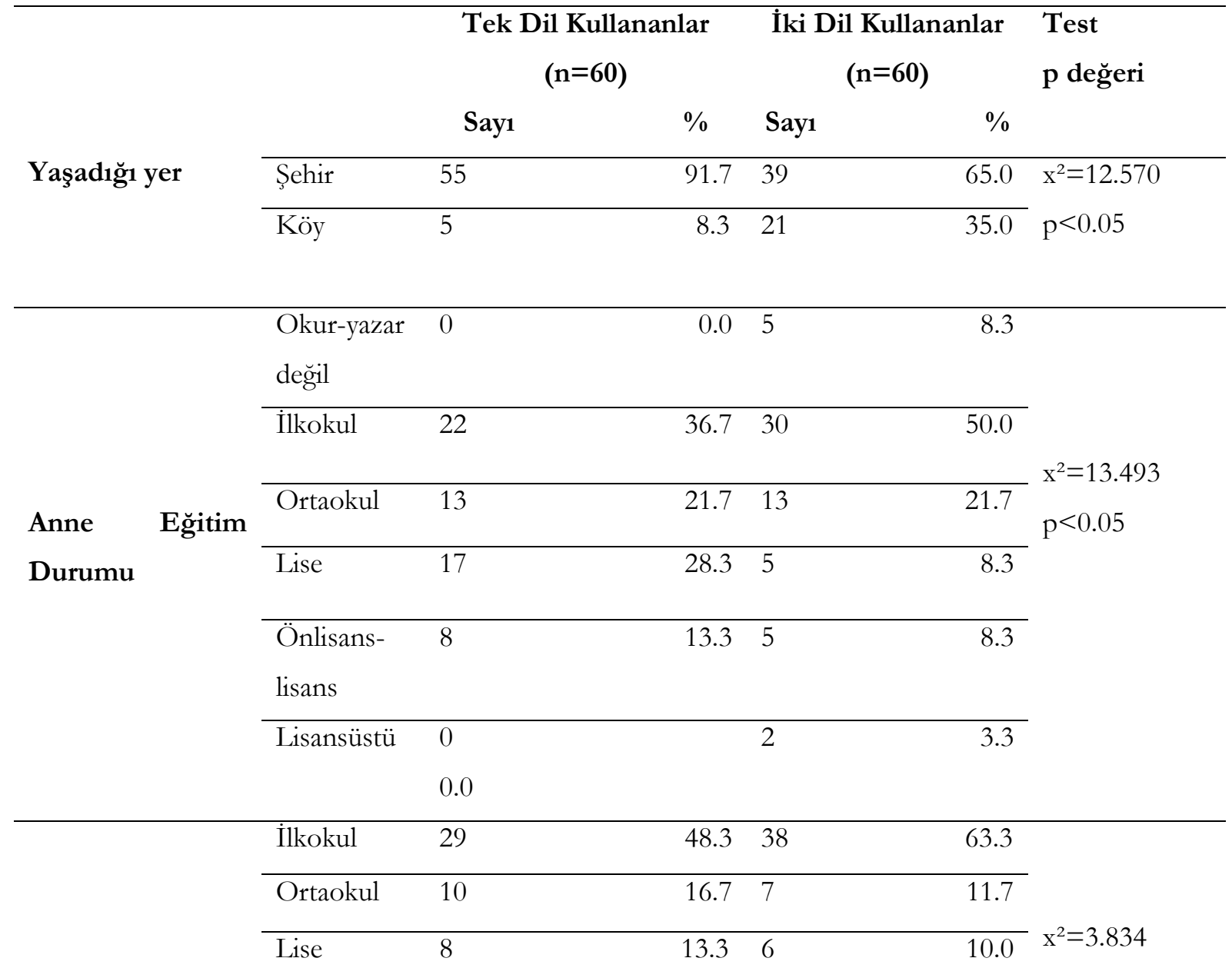




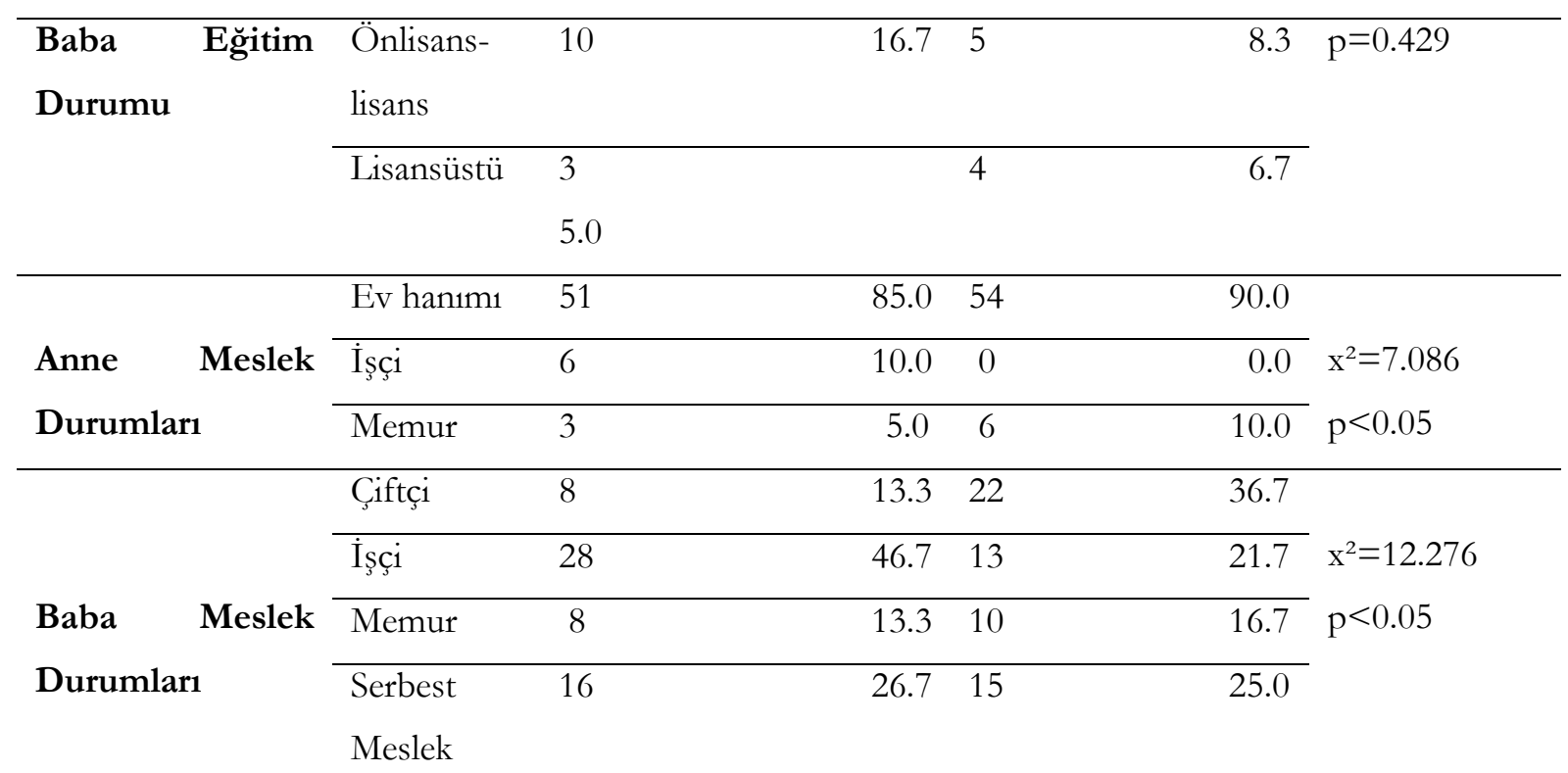

Tek dil kullananların \%091,7’si şehirde, \%8,3’ü köyde; iki dil kullananların \%66,0’i şehirde, \%35,0’i ise köyde yaşamaktadır. Tek dil kullananlar ile iki dil kullananların yaşadıkları yer ile ilgili değişken karşılaştırılmış, tek dil kullanan ailelerin ağırlıklı olarak şehir merkezinde yaşadıkları iki dil kullanan ailelerin ise köyde yaşadığı belirlenmiştir. Bu sonuçlara bakarak ailelerin şehir merkezinde ağırlıklı olarak tek dili (Türkçe'yi) tercih ettikleri yönünde değerlendirilmiştir $\left(\mathrm{x}^{2}=12.570, \mathrm{p}<0.05\right)$.

Çocukların anne eğitim düzeylerine bakıldığında, tek dil kullananların annelerinin \%36,7'si ilkokul, \%21,7’si ortaokul, \%28,3'ü lise, \%13,3’ü önlisans-lisans mezunu; iki dil kullananların annelerinin \%8,3’ü okur-yazar değil, \%50,0’si ilkokul, \%21,7’si ortaokul, \%8,3’ü lise, \%8,3’ü önlisans-lisans ve \%3,3’ü lisansüstü mezunudur. Ki-kare testi ile tek dil kullananlar ile iki dil kullananlar karşılaştırılmış, gruplar arasında annenin eğitim durumu yönünden istatistiksel olarak anlamlı fark bulunmuştur $\left(\mathrm{x}^{2}=13.493, \mathrm{p}<0.05\right)$.

Baba eğitim düzeylerine bakıldığında ise, tek dil kullananların babalarının \%48,3’ü ilkokul, \%16,7'si ortaokul, \%13,3’ü lise, \%16,7’si önlisans-lisans ve \%5,0’i lisansüstü mezunu; iki dil kullananların babalarının \%63,3’ü ilkokul, \%11,7’si ortaokul, \%10,0’u lise, \%8,3’ü önlisans-lisans, \%6,7'si lisansüstü mezunudur. Yapılan Ki-kare testi sonucunda ailelerinde tek dil kullanılan ve iki dil kullanılan çocukların babalarının eğitim durumlarının istatistiksel olarak anlamlı bir farklılık göstermediği belirlenmiştir $\left(\mathrm{x}^{2}=3.834, \mathrm{p}=0.429\right)$.

Anne meslekleri incelendiğinde, tek dil kullananların annelerinin \%85,0’i ev hanımı, \%10,0’u işçi ve \%5,0’i memur; iki dil kullananlarının annelerinin \%90,0’’ ev hanımı ve \%10,0'u memurdur. Tek dil kullananlar ile iki dil kullananlar, yapılan Ki-kare testi sonucunda annelerinin mesleklerine bağımlı olup gruplar arasında annelerinin mesleği ile aralarında bir ilişki olduğu belirleniştir. $\left(x^{2}=7.086\right.$, 
$\mathrm{p}<0.05)$. Anneleri işçi olan grupta tek dil kullanılırken, anneleri memur olan çocuklarda iki dil kullanımı daha yoğundur.

Baba meslek durumları incelendiğinde ise, tek dil kullananların babalarının \%13,3'ü çiftçi, \%46,7'si işçi, \%13,3’ü memur ve \%26,7'si serbest meslek; iki dil kullananların babalarının \%36,7’si çiftçi, \%21,7'si işçi, \%16,7'si memur ve \%25,0’i serbest meslektir. Yapılan Ki-kare testi sonucunda tek dil kullananlar ile iki dil kullananların babalarının meslekleri ile aralarında ilişki vardır $\left(\mathrm{x}^{2}=12.276\right.$, $\mathrm{p}<0.05)$. Babaları çiftçi olan çocuklarda iki dil kullanımının yoğunluğu köyde yaşamaları ile ilişkilendirilirken, babaları işçi olan çocukların ağırlıklı olarak tek dil kullanmaları şehir merkezinde yaşıyor olmaları ile ilişkilendirilebilinir. Bu durum ikamet edilen yerin çocuklarda kullanılan dil veya dillerin sayısını etkilediğini göstermektedir.

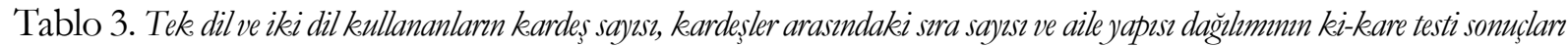

\begin{tabular}{|c|c|c|c|c|c|c|}
\hline & & \multicolumn{2}{|c|}{$\begin{array}{l}\text { Tek Dil Kullananlar } \\
\qquad(n=60)\end{array}$} & \multicolumn{2}{|c|}{$\begin{array}{l}\text { İki Dil Kullananlar } \\
\qquad(\mathrm{n}=60)\end{array}$} & \multirow[t]{2}{*}{$\begin{array}{l}\text { Test } \\
\text { pdeğeri }\end{array}$} \\
\hline & & Sayı & $\%$ & Sayı & $\%$ & \\
\hline Kardeş & Kardeşi Yok & 6 & 10.0 & 8 & 13.3 & $\mathrm{x}^{2}=0.710$ \\
\hline Say1s1 & 1 Kardeş & 24 & 40.0 & 21 & 35.0 & \multirow[t]{3}{*}{$\mathrm{p}=0.871$} \\
\hline \multirow[t]{2}{*}{ Değişkeni } & 2 Kardeş & 21 & 35.0 & 20 & 33.3 & \\
\hline & 3 ve Daha Fazla & 9 & 15.0 & 11 & 18.3 & \\
\hline \multirow{4}{*}{$\begin{array}{l}\text { Kardeşler } \\
\text { Arasındaki } \\
\text { Sıra Sayısı }\end{array}$} & İlk Çocuk & 16 & 26.7 & 18 & 30.0 & \multirow{4}{*}{$\begin{array}{l}x^{2}=0.549 \\
p=0.760\end{array}$} \\
\hline & Ortancalardan & 10 & 16.7 & 12 & 20.0 & \\
\hline & Biri & & & & & \\
\hline & Son Çocuk & 34 & 56.7 & 30 & 50.0 & \\
\hline \multirow[t]{2}{*}{ Aile Yapıs1 } & Çekirdek aile & 56 & 93.3 & 42 & 70.0 & \multirow{2}{*}{$\begin{array}{l}x^{2}=10.909 \\
p<0.05\end{array}$} \\
\hline & Geniş aile & 4 & 6.7 & 18 & 30.0 & \\
\hline
\end{tabular}

Tablo 3' te kardeş sayısı, kardeşler arası sıra sayısı ve aile yapısı değisskenleri incelenmiş ve tek dil kullananların \%10,0'unun tek çocuk, \%40,0'ının bir kardeşi, \%35,0'inin iki kardeşi ve \%15,0'inin 3 ve daha fazla kardeşi olduğu; iki dil kullananların \%13,3'ünün tek çocuk, \%35,0’inin bir kardeşi, \%33,3’ünün iki kardeşi ve \%18,3’ünün 3 ve daha fazla kardeşi olduğu bulguları Tablo’da verilmiştir. Ki-kare testiyle tek dil kullananlar ile iki dil kullananlar karşılaştırılmış ve kardeş sayısı açısından aralarında anlamlı bir farklılık olmadığı belirlenmiştir $\left(\mathrm{x}^{2}=0.710, \mathrm{p}=0.871\right)$.

Tek dil kullananların \%26,7'si ilk çocuk, \%16,7'si ortancalardan biri ve \%56,7'si son çocuk; iki dil kullananların \%30,0’u ilk çocuk, \%20,0'si ortancalardan biri ve \%50,0'si son çocuktur. Ki-kare testi 
ile tek dil kullananlar ile iki dil kullananlar karşılaştırılmış, gruplar arasında kardeş sayısı açısından anlamlı bir farklılık görülmemiştir $\left(\mathrm{x}^{2}=0.549, \mathrm{p}=0.760\right)$.

Tek dil kullananların aile yapıları incelenmiş, \%93,3’ü çekirdek ailede, \%6,7’si geniş ailede; iki dil kullananların \% 70,0’i çekirdek ailede ve \%30,0’u geniş ailede yaşadığı belirlenmiştir. Tek dil kullanan çocukların aileleri ile iki dil kullanan çocukların aileleri incelenmiş, yapılan Ki-kare testi sonucunda aile yapısına bağımlı oldukları ve aralarında istatistiksel olarak anlamlı bir fark olduğu belirlenmiştir $\left(x^{2}=10.909, \mathrm{p}<0.05\right)$. Bu durum geniş aile olarak yaşayan ailelerde kök ailelerin varlığının aile içinde iki dil kullanımını etkilediği ile ilişkilendirilmiştir.

Tablo 4. İki dilli ve tek dilli çocuklarn okul öncesi eğitim alma durumu ve kitap okuma durumlar

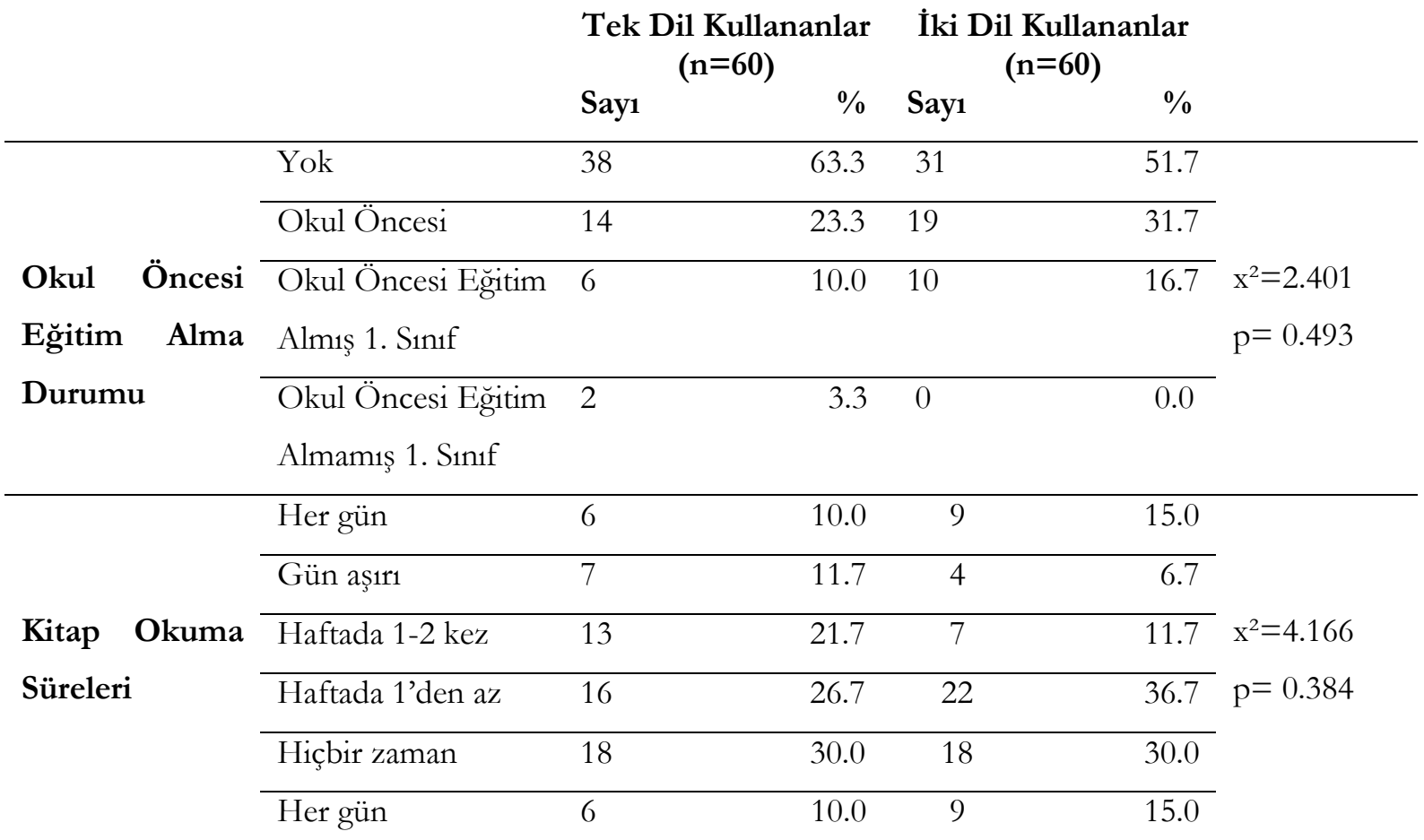

Tek dil kullananların okul durumlarına bakıldığında \%63,3'ünün okula gitmediği, \%23,3’ünün okul öncesi eğitim kurumuna gittiği, \%10,0’’nın okul öncesi eğitim görmüş 1.sınıf öğrencisi olduğu ve \%3,3’ünün okul öncesi eğitim görmemiş olup 1.sınıfa gittiği; iki dil kullananların ise \%51,7’sinin okula gitmediği, \%31,7'sinin okul öncesi eğitim kurumuna gittiği, \%16,7'sinin okul öncesi eğitim görmüş 1.sınıf öğrencisi olduğu belirlenmiştir. Yapılan Ki-kare testiyle tek dil kullanan çocuklar ile iki dil kullanan çocuklar arasında okul değişkeni açısından anlamlı bir farklılık olmadığı görülmüştür $\left(x^{2}=2.401, p=0.493\right)$.

Ebeveynlerin çocukla kitap okuma değişkeni gruplar arasında incelenmiş, tek dil kullananların ebeveynlerinin \%10.0'ının her gün, \%11.7'sinin gün aşırı, \%21.7'sinin haftada 1-2 kez, \%26.7’sinin 
haftada 1'den az olacak şekilde çocukla kitap okuduğu ve \%30'unun hiçbir zaman çocukla kitap okumadığı; iki dil kullananların ebeveynlerinin \%15.0’i her gün, \%6.7'sinin gün aşırı, \%11.7’sinin haftada 1-2 kez, \%36.7'sinin haftada 1'den az çocukla kitap okuduğu ve \%30'unun hiçbir zaman çocukla kitap okumadığı belirlenmiştir. Yapılan Ki-kare testi sonucunda her iki grup arasında istatistiksel olarak anlamlı bir farklılık olmadığı görülmüştür $\left(\mathrm{x}^{2}=4.166, \mathrm{p}=0.384\right)$.

Tablo 5. Cocuklarn ekran kullanmmna iliskin dağglımlarmmn ki-kare testi sonuclan

\begin{tabular}{|c|c|c|c|c|c|}
\hline & \multicolumn{2}{|c|}{$\begin{array}{c}\text { Tek Dil Kullananlar } \\
(\mathrm{n}=60)\end{array}$} & \multicolumn{2}{|c|}{$\begin{array}{l}\text { İki Dil Kullananlar } \\
\qquad(\mathrm{n}=60)\end{array}$} & \multirow[t]{2}{*}{$\begin{array}{l}\text { Test } \\
\text { p değeri }\end{array}$} \\
\hline & Sayı & $\%$ & Sayı & $\%$ & \\
\hline \multicolumn{6}{|c|}{$\begin{array}{l}\text { Aileye göre çocuğun ekran } \\
\text { süresi }\end{array}$} \\
\hline Çok fazla zaman ayırır & 16 & 26.7 & 11 & 18.3 & $x^{2}=3.016$ \\
\hline Biraz zaman ayırır & 18 & 30.0 & 22 & 36.7 & $\mathrm{p}=0.389$ \\
\hline Fazla zaman ayırmaz & 8 & 13.3 & 13 & 21.7 & \\
\hline Çok az zaman ayırır & 18 & 30.0 & 14 & 23.3 & \\
\hline
\end{tabular}

\begin{tabular}{|c|c|c|c|c|c|}
\hline \multicolumn{6}{|l|}{ Ekran başında geçirilen süre } \\
\hline \multicolumn{6}{|l|}{$0-2$ saat } \\
\hline 3-4 saat & 22 & 36.7 & 15 & 25.0 & $x^{2}=3.503$ \\
\hline $5-6$ saat & 21 & 35.0 & 27 & 45.0 & $\mathrm{p}=0.320$ \\
\hline \multirow[t]{2}{*}{6 saatten fazla } & 15 & 25.0 & 13 & 21.7 & \\
\hline & 2 & 3.3 & 5 & 8.3 & \\
\hline \multicolumn{5}{|c|}{ Ekran kullanmaya başlama } & $x^{2}=4.122$ \\
\hline yaş1 & 12 & 20.0 & 16 & 26.7 & $\mathrm{p}=0.127$ \\
\hline $0-2$ yaş & 48 & 80.0 & 41 & 68.3 & \\
\hline 3-4 yaş & 0 & 0.0 & 3 & 5.0 & \\
\hline \multicolumn{6}{|l|}{4 yaştan sonra } \\
\hline \multicolumn{5}{|l|}{ Ekranı kiminle kullandığı } & $x^{2}=7.021$ \\
\hline Yalnız & 22 & 36.7 & 12 & 20.0 & $\mathrm{p}<0.05$ \\
\hline Anne veya baba ile & 12 & 20.0 & 24 & 40.0 & \\
\hline Kardeş veya arkadaşları ile & 26 & 43.3 & 24 & 40.0 & \\
\hline
\end{tabular}

Tablo 5 incelendiğinde gruplarda çocukların ekran kullanım süresi incelenmiş, tek dil kullananların \%26,7’sinin çok fazla zaman ayırdığ,$\%$ 30,0’unun biraz zaman ayırdığ1, \%13,3’ünün fazla zaman ayırmadığı ve \%30,0’unun çok az zaman ayırdığı; iki dil kullananların ise \%18,3’ü çok fazla zaman 
ayırdığı, \%36,7’sinin biraz zaman ayırdığ1, \%21,7’sinin fazla zaman ayırmadığ1 ve \%23,3’ünün çok az zaman ayırdığı görülmüştür. Elde edilen bulgular iki grup arasında istatistiksel olarak anlamlı bir farklılık olmadığını göstermiştir $\left(x^{2}=3.016, p=0.389\right)$. Ekran başında geçirilen süreye bakıldığında tek dil kullananların \%36,7’sinin 0-2 saat, \%35,0’inin 3-4 saat, \%25,0’inin 5-6 saat ve \%3,3’ünün 6 saatten fazla zaman, iki dil kullananların ise \%25,0’inin 0-2 saat, \%45,0'inin 3-4 saat, \%21,7'sinin 56 saat ve \%8,3’ünün 6 saatten fazla zaman geçirdiği bulundu. Gruplar arasında ilişki görülmedi $\left(x^{2}=3.503, p=0.320\right)$. Tek dil kullananların \%20,0'si 0-2 yaş, \%80,0’i 3-4 yaş; iki dil kullananların ise \%26,7’si 0-2 yaş, \%68,3'ü 3-4 yaş ve \%5,0'inin 4 yaştan sonra ekranı kullanmaya başladığı bulundu. Elde edilen bulgular iki grup arasında istatistiksel olarak anlamlı bir farklılık olmadığını göstermiştir $\left(\mathrm{x}^{2}=4.122, \mathrm{p}=0.127\right)$. Tek dil kullananların \%36,7'si yalnız, \%20,0'si anne veya babalarıyla, \%43,3’ü kardeş veya arkadaşlarıyla; iki dil kullananların ise \%20,0'si yalnız, \%40,0’1 anne veya babalarıla, \%40,0’1 kardeş veya arkadaşlarıyla ekranı kullandıkları belirlenmiştir. Elde edilen bulgular iki grup arasında istatistiksel olarak anlamlı bir farkl1lı olduğunu göstermiştir $\left(x^{2}=7.021, p<0.05\right)$.

Tablo 6. Çocuklarn alıc dil puan bölümlerinden aldı̆̆ı puanlarm dağzlımlarmmn ki-kare testi sonuçları

\begin{tabular}{|c|c|c|c|c|c|}
\hline \multirow{3}{*}{ Alıcı Dil Bölümleri } & \multicolumn{2}{|c|}{ Tek Dil Kullananlar } & \multicolumn{2}{|c|}{ İki Dil Kullananlar } & \multirow{3}{*}{$\begin{array}{l}\text { Test } \\
\text { p değeri }\end{array}$} \\
\hline & \multicolumn{2}{|c|}{$(n=60)$} & \multicolumn{2}{|c|}{$(n=60)$} & \\
\hline & Say1 & $\%$ & Say1 & $\%$ & \\
\hline & 0 & 0.0 & 4 & 6.7 & \\
\hline rtalama üstü & 9 & 15.0 & 5 & 8.3 & $x^{2}=6.757$ \\
\hline rtalama & 24 & 40.0 & 30 & 50.0 & $\mathrm{p}=0.344$ \\
\hline rtalama altı & 22 & 36.7 & 16 & 26.7 & \\
\hline ayıf & 5 & 8.4 & 5 & 8.4 & \\
\hline
\end{tabular}

Grupların alıcı dil bölümleri dağılımı incelenmiş bulgular Tablo 6'da verilmiştir. Tek dil kullananların \%15,0’i ortalama üstü, \%40,0’’ ortalama, \%36,7'si ortalama alt1 ve \%8,4'ü zayıf; iki dil kullananların $\% 6,7$ 'si iyi, $\% 8,3$ 'ü ortalama üstü, \%50,0'si ortalama, $\% 26,7$ 'si ortalama altı ve $\% 8,4$ '̈u zayıf bölümdedir. Yapılan Ki-kare testinden elde edilen bulgular, iki grup arasında istatistiksel olarak anlamlı bir farklılık olmadığı, tek dil kullananlar ile iki dil kullananların alıcı dil bölümlerinin benzer olduğu belirlenmiştir $\left(\mathrm{x}^{2}=6.757, \mathrm{p}=0.344\right)$. Çalışmaya katılan çocukların alıcı dil bölümleri incelendiğinde iki dil kullanımı ile tek dil kullanımının alıcı dil üzerinde belirgin bir farklılık oluşturmadığ1 görülmüştür. 
Tablo 7. Çocuklarn ifade edici dil puan bölümlerinden aldĭğ puanlarm dağgllmlarmmn ki-kare testi sonuclar

İfade Edici Dil

Bölümleri
Tek Dil Kullananlar

$$
(n=60)
$$

İki Dil Kullananlar

$(n=60)$
Test

p değeri

\section{Say1}

Ortalama üstü

Ortalama

Ortalama altı

Zayıf

Çok zayıf
3

27

18

12

0

$$
\%
$$

45.0

30.0

20.0

0.0
Say1

4

30

12

12

2
$\%$

$$
6.7
$$

$50.0 \quad x^{2}=1.878$

$20.0 \mathrm{p}=0.758$

20.0

3.3

Tablo 7'de iki grupta yer alan çocukların ifade edici dil puanı bölümleri incelendiğinde, tek dil kullananların \%5,0'i ortalama üstü, \%45,0’i ortalama, \%30,0’u ortalama altı, \%20,0’si zayıf; iki dil kullananların \%6,7'si ortalama üstü, \%50,0'si ortalama, \%20,0'si ortalama altı, \%20,0'si zayıf ve \%3,3’ü çok zayıf bölümde yer almaktadır. Ki-kare testi sonucunda iki grup çocuk arasında ifade edici dil puanı bölümleri açısından anlamlı bir farklılık olmadığı belirlenmiştir $\left(\mathrm{x}^{2}=1.878, \mathrm{p}=0.758\right)$. Çalışmaya katılan çocukların ifade edici dil bölümleri incelendiğinde iki dil kullanımı ile tek dil kullanımının ifade edici dil üzerinde belirgin bir farklılık oluşturmadığı görülmüştür.

Tablo 8. Cocuklarn Sözel Dil Puam Bölümlerinin Dağgllmmmn Ki-Kare Testi Sonuclarn

Sözel Dil Bölümleri

Tek Dil Kullananlar

$$
(\mathrm{n}=60)
$$

\section{Say1}

Ortalama üstü

Ortalama

Ortalama altı

Zayıf

Çok zayıf
0

35

10

15

0
İki Dil Kullananlar

$(n=60)$

\section{Test}

p değeri

$\% \quad$ Say1 $\quad \%$


kullananlar ile iki dil kullananların sözel dil bölümleri açısından karşılaştırılmış iki dil kullanan gruptan kaynaklı istatistiksel olarak anlamlı fark bulunmuştur $\left(\mathrm{x}^{2}=15.883, \mathrm{p}<0.05\right)$. Çalışmaya katılan çocukların sözel dil performansı bölümleri incelendiğinde tek dil kullananlarda "zayıf” ve "ortalama" ağırlıklı olduğu, iki dil kullananlarda ise ortalama "altı" daha yoğundur. Bununla beraber tablo incelediğinde sözel dil performansı bölümünde tek dilli çocuklarda “ortalama üstü” ve "çok zayıf' düzeyinde çocuk bulunmazken, iki dilli grupta azımsanmayacak oranda olduğu görülmektedir.

Tablo 9. Tek Dil Kullananlarda Kitap Okuma Süresi ile Ahcu Dil ve Ifade Edici Dil Puan Ortalamalarnn Karşılaștırlmast

\begin{tabular}{|c|c|c|c|c|c|c|}
\hline \multirow{3}{*}{$\begin{array}{l}\text { Puan } \\
\text { Türü }\end{array}$} & \multicolumn{5}{|c|}{ Kitap okuma süresi } & \multirow[b]{2}{*}{$\begin{array}{l}\text { Test } \\
\text { p değeri }\end{array}$} \\
\hline & $\begin{array}{l}\text { Her gün } \\
(n=6)\end{array}$ & $\begin{array}{l}\text { Gün aşır1 } \\
(n=7)\end{array}$ & $\begin{array}{l}\text { Haftada 1-2 } \\
\text { kez }(n=13)\end{array}$ & $\begin{array}{l}\text { Haftada } \\
\text { 1'den az } \\
(n=16)\end{array}$ & $\begin{array}{l}\text { Hiçbir } \\
\text { zaman } \\
(n=18)\end{array}$ & \\
\hline & ort \pm ss & ort $\pm s s$ & ort \pm ss & ort \pm ss & ort \pm ss & \multirow{2}{*}{$\begin{array}{l}F: 1.326 \\
p=0.272\end{array}$} \\
\hline $\begin{array}{l}\text { Alıcı dil } \\
\text { puanı }\end{array}$ & $101.33 \pm 13.76$ & $100.57 \pm 16.91$ & $95.54 \pm 11.77$ & $90.75 \pm 9.07$ & $94.56 \pm 11.51$ & \\
\hline $\begin{array}{l}\text { İfade } \\
\text { edici dil } \\
\text { puanı }\end{array}$ & $87.00 \pm 11.35$ & $84.57 \pm 8.26$ & $94.92 \pm 11.74$ & $88.56 \pm 10.33$ & $91.67 \pm 12.09$ & $\begin{array}{l}F: 1.325 \\
p=0.272\end{array}$ \\
\hline
\end{tabular}

Tek dil kullananlarda kitap okuma süresi ile alıcı dil ve ifade edici dil puan ortalamaları karşılaştırılmış olup, bulgular Tablo 9'da gösterilmiştir. Yapılan ANOVA testi sonucunda kitap okuma süresinin alıcı dil ve ifade edici dil puan ortalamalarını etkilemediği bulundu (F: 1.326 $\mathrm{p}=0.272 ; \mathrm{F}: 1.325 \mathrm{p}=0.272)$.

Tablo 10. Tek dil kullananlarda ekran kullanma süresi ile alıc dil ve ifade edici dil puan ortalamalarmnn karşılaștırlması

\begin{tabular}{|c|c|c|c|c|c|}
\hline \multirow{4}{*}{$\begin{array}{l}\text { Puan } \\
\text { Türü }\end{array}$} & \multicolumn{4}{|c|}{ Ekranı kullanım süresi } & \multirow{3}{*}{$\begin{array}{l}\text { Test } \\
\text { p değeri }\end{array}$} \\
\hline & $0-2$ saat & $2-4$ saat & 4-6 saat & 6 saatten & \\
\hline & $(n=22)$ & $(n=21)$ & $(n=15)$ & fazla & \\
\hline & & & & $(n=2)$ & \\
\hline & ort \pm ss & ort $\pm s s$ & ort $\pm s s$ & ort $\pm s s$ & \\
\hline & & & & & $5: 1.1 / 2$ \\
\hline & $96.82 \pm 9.75$ & $97.10 \pm 13.19$ & $90.67 \pm 12.99$ & $89.50 \pm 14.85$ & $\mathrm{p}=0.328$ \\
\hline & $\begin{array}{r}\text { Çocukluk Çalış } \\
\text { Cilt } 4\end{array}$ & $\begin{array}{l}1 \text { Dergisi } \\
3 \cdot \text { Ekim }\end{array}$ & 2020 & $\begin{array}{l}\text { Journal of Early Chil } \\
\text { Volume } 4 \cdot \text { Issue } 3 \cdot \text { C }\end{array}$ & $\begin{array}{l}\text { ood Studies } \\
\text { tober }\end{array}$ \\
\hline
\end{tabular}




\begin{tabular}{llllll}
\hline $\begin{array}{l}\text { Alıc1 dil } \\
\text { puanı }\end{array}$ & & & \\
\hline & & & & \\
\hline Iffade & $94.14 \pm 10.80$ & $89.05 \pm 11.21$ & $87.00 \pm 11.64$ & $84.50 \pm 0.71$ & F: 1.597 \\
edici dil & & & & $\mathrm{p}=0.200$ \\
puanı & & & \\
\hline
\end{tabular}

Tek dil kullananlarda ekranı kullanma süresi ile alıcı dil ve ifade edici dil puan ortalamaları ANOVA testi ile karşılaştırılmış olup, bulgular Tablo 10'da gösterilmiştir. Ekranı kullanım süresi ile alıcı dil ve ifade edici dil puan ortalamaları arasında istatistiksel olarak fark bulunmamıştır (F: 1.172 $\mathrm{p}=0.328 ; \mathrm{F}: 1.597 \mathrm{p}=0.200)$.

Tablo 11. Tek dil kullananlarda ekramı kullanma yaşı ile alıı dil ve ifade edici dil puan ortalamalarmmn karşılaștırlması

\section{Ekranı kullanma yaşı}

Puan Türü

Test

\begin{tabular}{|c|c|c|}
\hline $0-2$ yaş & $2-4$ yaş & p değeri \\
\hline$(n=12)$ & $(n=48)$ & \\
\hline
\end{tabular}

t:-1.007

\begin{tabular}{lccc} 
Alıcı dil puanı & $92.00 \pm 12.48$ & $95.92 \pm 11.94$ & $\mathrm{p}=0.318$ \\
\hline İfade edici dil puanı & $98.75 \pm 12.48$ & $88.13 \pm 9.95$ & $\mathrm{t}: 3.142$ \\
& & $\mathrm{p}<0.05$ \\
\hline
\end{tabular}

Tek dil kullananlarda ekranı kullanma yaşı ile alıcı dil ve ifade edici dil puan ortalamaları karşılaştırılmış olup, bulgular Tablo 11'de gösterilmiştir. Yapılan t-testi sonucunda ekranı kullanma yaşı ile alıcı dil puan ortalaması arasında istatistiksel olarak anlamlı fark bulunmadı (t: -1.007 $\mathrm{p}=0.318)$. Ekranı kullanma yaşı ile ifade edici dil puan ortalaması arasında istatistiksel olarak anlamlı fark bulundu (t: $3.142 \mathrm{p}<0.05)$. Farkın 0-2 yaş aralı̆̆ında olan gruptan kaynaklandığı görüldü. Görülen bu fark ekran kullanımının 0-2 yaş dönemindeki ifade edici dil puan ortalamasının, 2-4 yaş grubundaki çocukların ifade edici dil puanı ortalamalarından daha fazla olduğu ve ekran kullanımının 2-4 yaş aralığında ifade edici dil gelişimi üzerindeki olumsuz etkisinden kaynaklandığı düşünülmektedir.

Tablo 12. Tek Dil Kullananlarda Kitap Okuma Süresi ile Aluc Dil ve Ifade Edici Dil Puan Ortalamalarmn Karşılaștırlması 


\begin{tabular}{|c|c|c|c|c|c|c|}
\hline \multirow{3}{*}{$\begin{array}{l}\text { Puan } \\
\text { Türü }\end{array}$} & \multicolumn{5}{|c|}{ Kitap okuma süresi } & \multirow[b]{2}{*}{$\begin{array}{l}\text { Test } \\
\text { p değeri }\end{array}$} \\
\hline & $\begin{array}{l}\text { Her gün } \\
(n=9)\end{array}$ & $\begin{array}{l}\text { Gün aşır1 } \\
(n=4)\end{array}$ & $\begin{array}{l}\text { Haftada 1-2 } \\
\text { kez }(n=7)\end{array}$ & $\begin{array}{l}\text { Haftada } \\
\text { 1'den az } \\
(n=22)\end{array}$ & $\begin{array}{l}\text { Hiçbir } \\
\text { zaman } \\
(n=18)\end{array}$ & \\
\hline & ort $\pm s s$ & ort \pm ss & ort \pm ss & ort \pm ss & ort \pm ss & \multirow{2}{*}{$\begin{array}{l}F: 5.381 \\
\mathrm{p}<0.05\end{array}$} \\
\hline $\begin{array}{l}\text { Alıcı dil } \\
\text { puanı }\end{array}$ & $105.11 \pm 12.11$ & $98.75 \pm 14.08$ & $108.29 \pm 16.12$ & $94.09 \pm 13.31$ & $87.00 \pm 9.52$ & \\
\hline $\begin{array}{l}\text { İfade } \\
\text { edici dil } \\
\text { puanı }\end{array}$ & $101.44 \pm 8.62$ & $96.75 \pm 17.21$ & $98.00 \pm 9.88$ & $93.23 \pm 12.95$ & $83.56 \pm 13.83$ & $\begin{array}{l}F: 3.817 \\
p<0.05\end{array}$ \\
\hline
\end{tabular}

İki dil kullananlarda kitap okuma süresi ile alıcı dil ve ifade edici dil puan ortalamaları karşılaştırılmış olup, bulgular Tablo 12'de gösterilmiştir. Yapılan ANOVA testi sonucunda kitap okuma süresinin alıcı dil ve ifade edici dil puan ortalamaları üzerinde istatistiksel olarak anlamlı bir fark oluşturduğu belirlenmiştir (F: $5.381 \mathrm{p}<0.05$; F: $3.817 \mathrm{p}<0.05$ ). Farkın hangi gruplar arasında olduğunu belirlemek için çoklu karşılaştırma testlerinden "Tukey” testi uygulanmış ve analiz sonucunda haftada bir-iki kez ve her gün kitap okuyan grupların, kitap okuma süreleri hiçbir zaman, gün aşırı, haftada 1'den az kitap okuyan gruplara kıyasla alıcı dil puan ortalamaları daha yüksek bulunmuştur.

Tablo 13. İki dil kullananlarda ekran kullanma süresi ile alıc dil ve ifade edici dil puan ortalamalarmın karşılaştırlması

\section{Ekranı kullanım süresi}

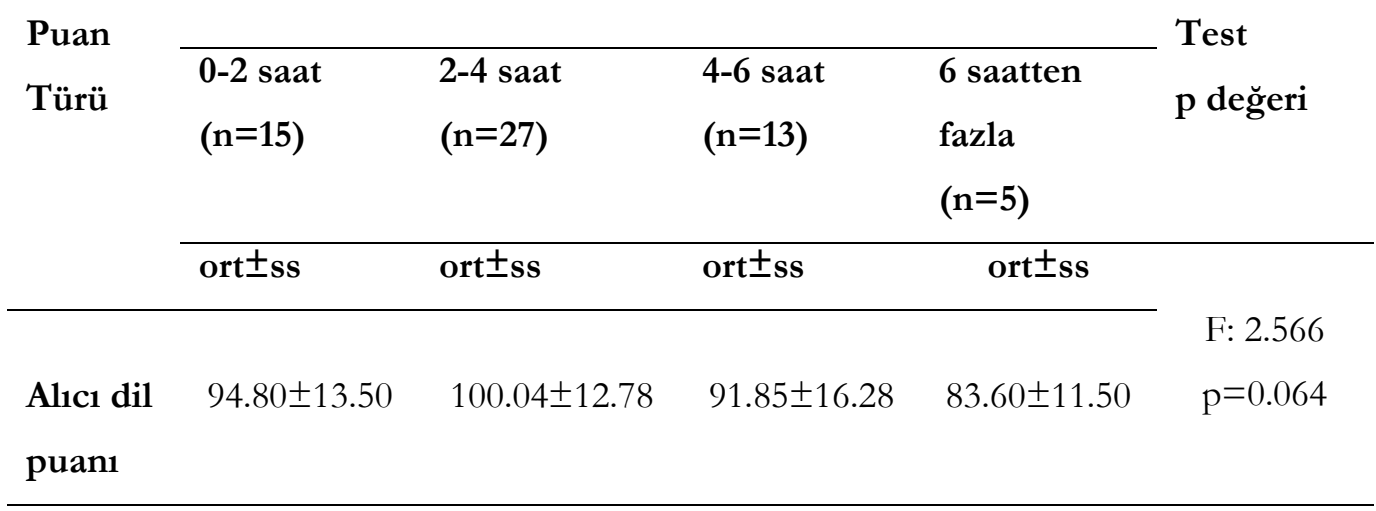




\begin{tabular}{llllll}
\hline İfade & $94.67 \pm 15.70$ & $94.11 \pm 13.53$ & $87.69 \pm 13.19$ & $88.00 \pm 10.65$ & F: 0.939 \\
edici dil & & & & $\mathrm{p}=0.428$ \\
puanı & & & \\
\hline
\end{tabular}

İki dil kullananlarda ekranı kullanma süresi ile alıcı dil ve ifade edici dil puan ortalamaları karşılaştırılmış olup, bulgular Tablo 13'te gösterilmiştir. Yapılan ANOVA testi sonucunda ekranı kullanım süresi ile alıcı dil ve ifade edici dil puan ortalamaları üzerinde istatistiksel olarak anlamlı bir etki bulunmamışır ( $\mathrm{F}: 2.566 \mathrm{p}=0.064 ; \mathrm{F}: 0.939 \mathrm{p}=0.428)$.

Tablo 14. İki dil kullananlarda ekram kullanma yaşı ile ahcı dil ve ifade edici dil puan ortalamalarmmn karşılaştırlması

\begin{tabular}{|c|c|c|c|c|}
\hline \multirow{3}{*}{ Puan Türü } & & rant kullanms & & \multirow[b]{2}{*}{$\begin{array}{l}\text { Test } \\
\text { p değeri }\end{array}$} \\
\hline & $\begin{array}{l}0-2 \text { yaş } \\
(n=16)\end{array}$ & $\begin{array}{l}2-4 \text { yaş } \\
(n=41)\end{array}$ & $\begin{array}{l}4 \text { yaştan sonra } \\
(n=3)\end{array}$ & \\
\hline & ort \pm ss & ort $\pm s s$ & ort \pm ss & \\
\hline \multirow[t]{2}{*}{ Alıcı dil puanı } & $97.00 \pm 14.63$ & $95.15 \pm 14.66$ & $94.00 \pm 6.93$ & $\mathrm{p}=0.893$ \\
\hline & $96.63 \pm 14.77$ & $90.66 \pm 13.37$ & $92.67 \pm 15.31$ & F:1.073 \\
\hline İfade edici dil puanı & & & & $\mathrm{p}=0.349$ \\
\hline
\end{tabular}

İki dil kullananlarda ekranı kullanma yaşı ile alıcı dil ve ifade edici dil puan ortalamaları karşılaştırılmış olup, bulgular Tablo 14'te gösterilmiştir. Yapılan ANOVA testiyle ekranı kullanma yaşı ile alıcı dil ve ifade edici dil puan ortalamaları arasında istatistiksel olarak anlamlı fark bulunmamıştır (F:0.114 p=0.893; F: 1.073 p=0.349).

\section{TARTIŞMA}

Araştırmaya katılan çocukların sosyo-demografik özellikleri Tablo 1'de incelenmiştir. Cinsiyet faktörü yönünden incelendiğinde kızların \%45,5’i tek dil, \%54,5’i ise iki dil; erkeklerin \%55,6’s1 tek dil, \%44,4’ü ise iki dil kullanmaktadır. Burada araştırmaya katılan çocukların cinsiyet açısından birbirine yakın iki gruptan oluştuğu görülmektedir. Tulu (2009), iki dilli ve tek dilli çocukların dil gelişim puanlarının cinsiyet ile ilişkisi incelenmiş ve anlamlı fark olmasa da kız çocukların erkeklerden daha ileri oldukları belirlemiştir. Canan (2012), iki dilli kızların üstdil becerilerinin erkeklerden anlamlı derecede yüksek olduğu bulunmuştur. Yaş faktörü yönünden incelendiğinde ise tek dil kullananların yaş ortalamasının $\square=54.80 \pm 15.83$, iki dil kullananların yaş ortalamasının $\square=60.48 \pm 14.74$ olduğu belirlenmiştir. Tek dil kullananların \%13,3’ü 24-36 ay, \%20,0'si 36-48 ay, 
\%20,0’si 48-60 ay, \%33,3’ü 60-72 ay, \%13,3’ü 72-84 ay grubunda; iki dil kullananların \%11,7'si 2436 ay, \%6,7’si 36-48 ay, \%23,3’ü 48-60 ay, \%35,0’i 60-72 ay ve \%23,3’ü 72-84 ay grubunda yer almaktadır. Tek dil kullananlar ile iki dil kullananların yaşlarının birbirine benzer olduğu görülmüştür. Bu veriler iki grup çocuğun yaş ve cinsiyet açısından farklılık göstermediği ve birbirine benzer iki grup olduğu değerlendirilmiştir. Canan (2012), yapmış olduğu çalışmada üstdil becerileri işlemlerinde yalnızca küçük yaş grubu karşılaştırılmış ve tek dillilerin iki dillilerden daha yüksek performans gösterdikleri görülmüştür.

Yapılan analizler sonucunda tek dil kullananlar ile iki dil kullananların yaşadıkları yer değişkeni Tablo 2'de karşılaştırılmış, iki grup arasında istatistiksel olarak anlamlı bir fark olduğu bulunmuştur. Tek dil kullanan ailelerin ağılıklı olarak şehir merkezinde yaşadıkları iki dil kullanan ailelerin ise ağırlıklı olarak köyde yaşadığı belirleniştir. Bu sonuçlara bakarak ailelerin şehir merkezinde ağırlıklı olarak tek dil (Türkçe'yi) tercih ettikleri yönünde değerlendirilmiştir. Koşan (2015), Araştırmasında okul öncesi eğitim desteği alan ve almayan çift dilli çocukların okula hazır bulunuşluk düzeylerine bakmış ve ailenin sosyo-ekonomik durumunun çocuklanın dil gelişiminde etkili olduğunu belirtmiştir. Görsel ayırt etme, başlangıç seslerini ayırt etme alt testleri, hikâye anlama ve matematik becerisi alanlarında üst sosyo-ekonomik grubun lehine anlamlı fark bulunmuştur.

Tek dil kullananlar ile iki dil kullananlar karşılaştırılmış, gruplar arasında annenin eğitim durumu yönünden istatistiksel olarak anlamlı fark olduğu ve bu farkın iki dilli çocukların anne eğitim düzeylerinden kaynaklandığı belirlenmiştir. Şeker (2010), yaptığı çalışmada Okul öncesi dönemde Türkçe ve yabancı dilde eğitim alan altı yaş çocukların Türkçe dil kullanım becerileri ile anne eğitim düzeyleri arasında ilişki olup olmadığına bakılmış ve eğitim düzeyi yüksek anneler lehine anlamlı fark olduğunu belirtmişlerdir. Buna karşın baba eğitim durumları incelenmiş ve baba eğitim düzeyinin çocukların dil gelişimi arasında istatistiksel olarak anlamlı bir ilişki olmadığı belirlenmiştir. Tulu (2009), yapmış olduğu çalışmada iki dilli ve tek dilli 4-7 yaş çocukların dil gelişimlerine etki eden faktörlerden baba eğitim durumunun etkilerini incelemiştir. Gruplar arasinda anlamlı bir farklılık olmadığı sonucuna ulaşmıştır.

Tek dil kullananlar ile iki dil kullanılan ailelerdeki çocukların annelerinin meslekleri incelenmiş, annelerinin mesleği ile gruplar arasında istatistiksel olarak anlamlı bir farklılık olduğu belirlenmiştir. Anneleri işçi olan grupta tek dil kullanılırken, anneleri memur olan çocuklarda iki dil kullanımı daha yoğun olduğu görülmüştür. Şeker (2010), Türkçe ve yabancı dil eğitimi alan 6 yaş grubu çocuklarının Türkçe dil kullanma becerileri ile anne çalışma durumu arasındaki ilişkiye bakılmış ve anlamlı bir fark bulunamamıstır. Tek dil kullananlar ile iki dil kullananların babalarının meslekleri Tablo 2'de karşılaştırılmış, aralarında anlamlı bir farklılık olduğu ve babaları çiftçi olan çocuklarda iki dil kullanımının yoğunluğu köyde yaşamaları ile ilişkilendirilirken, babaları işçi olan çocukların ağırlıklı 
olarak tek dil kullanmalarının şehir merkezinde yaşıyor olmaları ile ilişkilendirilmiştir. Bu durum ikamet edilen yerin çocuklarda kullanılan dil veya dillerin sayısını etkilediğini göstermektedir.

Araştırmaya katılan çocuk gruplarının, kardeş sayısı, kardeşler arasındaki sıra sayısı ve aile yapıları Tablo 3'te incelenmiştir. Tek dil kullananlar ile iki dil kullanan ailelerin çocukları karşılaştırılmış, kardeş sayısı ve çocuklar arasında kaçıncı sırada oldukları değişkenlerinin benzer olduğu belirlenmiştir. Şeker (2010), 6 yaş grubu çocuklar ile yaptığı çalışmada kardeş sayısı faktörünün Türkçe dil kullanım becerileri üzerinde anlamlı bir farklılığa neden olmadığını belirtmiştir. Araştırmaya katılan çocuk gruplarının, aile yapıları karşılaştırılmış ve aralarında istatistiksel olarak anlamlı bir ilişki olduğu ve geniş aile yapılarında iki dil kullanımının daha yoğun olduğu görülmüştür. Tek dil kullananlar ile iki dil kullananlar arasında okul değişkeni ve çocukla kitap okuma sıklığ1 değişkenleri Tablo 4’te incelenmiş ve bu değişkenler açısından ilişki olmadığı görülmüştür. Tetik (2017), yapmış olduğu araştırmada diyaloğa dayalı ve geleneksel birlikte kitap okuma ile düzenli kitap okumanın 4-5 yaş çocuklarında kelime bilgisi ve dil gelişimine olumlu etkisi olduğunu belirtmiştir. Özellikle diyaloğa dayalı okumanın çocuğun dil gelişim alanını daha fazla desteklediği sonucuna ulaşmıştır.

Grupların aileye göre çocuğun ekran kullanım süreleri Tablo 5'te incelenmiş, tek dil kullananlar ile iki dil kullananların ekran kullanma süreleri açısından benzer oldukları, gruplar arasında anlamlı ilişki olmadığı belirlenmiştir. Ancak tek dil kullananlar ile iki dil kullananların ekranı kiminle izlediği değişkeni açısından incelendiğinde gruplar arasında anlamlı farklılık olduğu görülmüştür. Yapılan bu karşılaştırmada iki dilli çocukların ağırlıklı olarak anne veya babaları ve kardeş veya arkadaşları ile izlediği belirlenirken, tek dilli çocuklarda yalnız ve kardeş veya arkadaşları ile kullandıkları belirlenmiştir. Karaca ve arkadaşları (2007), yapmış oldukları çalışmada televizyon reklam içeriklerinin çocuklar üzerindeki etkilerini araştırmışlardır. Çalışma sonucunda ebeveynlerin çoğunluğunun reklamların çocuğun, yaratıcılığını, hayal gücünü ve tüketim alışkanlıklarını olumsuz etkilediğini ve ayrıca çocukların algılama ve psikolojik gelişim süreçlerini olumsuz etkilemekle beraber dil gelişim problemlerine de neden olduğunu belirttiklerini ifade etmişlerdir.

Gruplanın alıcı dil bölümleri dağılımı Tablo 6'da incelenmiş ve tek dil kullananlar ile iki dil kullananların alıcı dil bölümlerinin benzer olduğu belirlenmiştir. Yine grupların ifade edici dil bölümleri Tablo 7'de incelenmiş ve grupların benzer olduğu, iki dil kullanımı ile tek dil kullanımının ifade edici dil bölümleri üzerinde belirgin bir farklılık oluşturmadığı görülmüştür. Grupların sözel dil performansı bölümü Tablo 8'de incelendiğinde, iki dil kullanan gruptan kaynaklı istatistiksel olarak anlamlı fark bulunmuştur. Tulu (2009), yapmış olduğu çalışmada iki dilli ve tek dilli çocukların dil gelişimine etki eden faktörler incelenmiş, tek dilli çocukların Peabody dil testinde iki dilli çocuklardan daha yüksek puan aldıklarını belirtmiştir. Şeker (2010), çalışmasında okul öncesi 
dönemde yabancı dil ediniminin çocukların dil gelişimine katkısının olup olmadığı araştırılmıştır. Araştırmada Layza Eskinazi tarafindan Türkçe'ye uyarlanan Language Processing Test (Dil Kullanım Ölçeği) kullanılmış ve okul öncesi eğitimi alan ve almayan 6 yaş grubu çocukların dil kullanım becerilerinin ölçülmesi amaçlanmıştır. Araştırma sonucunda bütün alt boyutlarda yabancı dil eğitimi alan çocukların anlamlı derecede daha yüksek puan aldıkları belirtilmiştir. Canan (2012), Okul Öncesi Dönem Çocuklarda İki Dilliliğin Zihin Kuramı Gelişimi Üzerine Etkisi çalışmasında İki dilli ve tek dilli çocukların dil gelişim düzeyleri incelenmiş ve çocukların almış olduğu TEDİL puanları arasında anlamlı fark bulunamamıştır. Ancak çalışma kapsamında çalışmaya dahil edilen iki dilli ve tek dilli çocukların zihin kuramı gelişimi puanları arasında iki dilli çocuklar lehine anlamlı fark bulunmuştur. Koşan (2015), yapmış olduğu araştırmada okul öncesi eğitim alan ve almayan iki dilli çocukların okula hazır bulunuşluklarında; evde sıklıkla konuşulan dilin anlamlı farklılık yarattığı, bu farkın evde yalnızca Türkçe konuşanlar lehine olduğunu belirtmiştir.

Tek dil kullananlarda kitap okuma süresi ile alıcı dil ve ifade edici dil puan ortalamaları Tablo 9'da karşılaştırılmış olup, yapılan istatistiksel analiz sonucunda kitap okuma süresinin alıcı dil ve ifade edici dil puan ortalamalarını etkilemediği görülmüştür. İki dil kullananlarda kitap okuma süresi ile alıcı dil ve ifade edici dil puan ortalamaları Tablo 12'de karşılaştırılmış olup, yapılan istatistiksel analiz sonucunda kitap okuma süresi ile alıcı dil ve ifade edici dil puan ortalamaları arasında istatistiksel olarak anlamlı fark olduğu görülmüştür. Haftada bir-iki kez ve her gün kitap okuyan grupların, kitap okuma süreleri hiçbir zaman, gün aşırı, haftada 1'den az kitap okuyan gruplara kıyasla alıcı dil puan ortalamalarının daha yüksek olduğu bulunmuştur. Düzenli kitap okumanın alıcı dil gelişimi üzerindeki etkisi belirlenmiştir. Ping (2012), okul öncesi dönem çocuklarında diyaloğa dayalı kitap okumada grup etkisinin dil öğrenimini arttırdığını belirtmiş̧tir. Tetik (2017), yapmış olduğu araştırmada diyaloğa dayalı ve geleneksel birlikte kitap okuma ile düzenli kitap okumanın 45 yaş çocuklannda kelime bilgisi ve dil gelişimine olumlu etkisi olduğunu belirtmiştir. Özellikle diyaloğa dayalı okumanın çocuğun dil gelişim alanını daha fazla desteklediği sonucuna ulaşmıştır. Erdoğan ve arkadaşları (2017), Ev Merkezli Diyaloğa Dayalı Okumanın 4-5 Yaş Çocuklarının Dil Gelişimine Olan Etkileri adlı çalışmalarında ev merkezli diyaloğa dayalı okumanın 4-5 yaş çocuklarının alıcı ve ifade edici dil gelişimleri üzerindeki etkileri incelemişlerdir. Çalışma 32 ebeveyn ve çocuk ile yapılmış ve dil gelişim düzeyleri TEDİL aracı ile ölçülmüştür. Çalışma grubuna 6 hafta süresince haftada 3 gün olacak şekilde ebeveynlerin çocuklara diyaloğa dayalı kitap okumaları istenmiş ve çalışma öncesi ve sonrası yapılan TEDİL sonuçları karşılaştırılmış ve diyaloğa dayalı kitap okumanın çocukların dil gelişimlerini olumlu yönde etkilediğini belirtmişlerdir.

Tek dil kullananlarda ekranı kullanma süresi ile alıcı dil ve ifade edici dil puan ortalamaları Tablo 10'da karşılaştırılmış ve yapılan istatistiksel analiz sonucunda çocukların ekranı kullanım süresi ile 
alıcı dil ve ifade edici dil puan ortalamaları arasında anlamlı fark olmadığı belirlenmiştir. İki dil kullananlarda ekranı kullanma süresi ile alıcı dil ve ifade edici dil puan ortalamaları Tablo 13'te karşılaştırılmış ve çocukların ekranı kullanım süresi ile alıcı dil ve ifade edici dil puan ortalamaları arasında istatistiksel olarak anlamlı fark olmadığı görülmüştür. Karaca ve arkadaşları (2007), yapmış oldukları çalışmada televizyon reklam içeriklerinin çocuklar üzerindeki etkilerini araştırmışlardır. Çalışma sonucunda ebeveynlerin çoğunluğunun reklamların çocuğun, yaratıcıllğıın, hayal gücünü ve tüketim alışkanlıklarını olumsuz etkilediğini ve ayrıca çocukların algılama ve psikolojik gelişim süreçlerini olumsuz etkilemekle beraber dil gelişim problemlerine de neden olduğunu belirttiklerini ifade etmişlerdir.

Tek dil kullananlarda ekranı kullanma yaşı ile alıcı dil ve ifade edici dil puan ortalamaları Tablo 11'de karşılaştırılmış olup, ekranı kullanma yaşı ile alıcı dil puan ortalaması arasında istatistiksel olarak anlamlı fark bulunmazken, ekranı kullanma yaşı ile ifade edici dil puan ortalaması arasında istatistiksel olarak anlamlı fark olduğu görülmüştür. Farkın 0-2 yaş aralığında olan gruptan kaynaklandığı belirlenmiştir. Görülen bu fark ekran kullanımının 0-2 yaş döneminde ifade edici dil üzerinde olumlu etkisi olduğunu değil, 2-4 yaş grubunda ekran kullanımının ifade edici dil gelişimi üzerindeki olumsuz etkisinden kaynaklandığı düşünülmektedir. İki dil kullananlarda ekranı kullanma yaşı ile alıcı dil ve ifade edici dil puan ortalamaları Tablo 14’te karşılaştırılmış ve çocukların ekranı kullanma yaşı ile alıcı dil ve ifade edici dil puan ortalamaları arasında istatistiksel olarak anlamlı fark olmadığı belirlenmiştir. Tümkan (2007), çocuğun televizyon karşısındayken annebabanın sevgi ve ilgisinden ayrı, sosyal ve duygusal uyaranlardan yoksun bırakılmasının bebeğin (02 yaş) hem sosyal hem de dil gelişimini olumsuz etkilediğini belirtmiştir. Büyükbaykal (2007), televizyonun çocuğun sözcük dağarcığı gelişimine olumlu etkisi olduğunu ve ebeveynler tarafindan seçilen eğitsel programların izletilmesi gerektiğini belirtmiştir. Kalan (2010), ebeveynlerin medya okuryazarlığı üzerine yaptığı çalışmada, ebeveynlerin medya okuryazarllğı hakkında kavram bilgisine sahip olmadıklarını belirtmiştir. Ayrıca çalışmada ebeveynlerin çocuklarını ekranın zararlarından korumak için çocuk kanallarını izlettirme yoluna gittiklerini belirtmiştir.

\section{SONUÇ VE ÖNERLER}

Yaptığımız bu araştırmada temelde erken çocukluk döneminde iki dilliliğin çocukların alıcı ve ifade edici dil gelişimine etkisi incelenmiştir. Araştırma sonucunda; iki dilli ve tek dilli çocukların alıcı dil, ifade edici dil becerileri ve sözel dil performansları karşılaştırılmış ve iki grup arasında anlamlı fark olmadığı görülmüştür. Araştırmada ayrıca çalışmaya dahil edilen her iki grubun dil gelişimlerine etki edebilecek diğer faktörler de ele alınmıştır. Bu faktörlerden; yaş, cinsiyet, baba eğitim düzeyi, kardeş sayısı, kardeşler arasındaki sıra sayısı, okul durumu, kitap okuma sıklı̆̆1, ekran kullanım süresi açısından anlamlı fark bulunmazken, çocukların yaşadığı yer, anne eğitim durumu, anne ve baba 
mesleği, aile yapısı, çocukla kitap okuma sıklığı, ekran kullanma yaşı ve ekranı kiminle kullandığı değişkenleri açısından iki grup arasında iki dilli grup lehine anlamlı fark oluştuğu belirlenmiştir.

Elde edilen bu bilgiler ışığında aşağıdaki önerilerde bulunulmuştur.

$\checkmark$ Kitap okuma sürelerinin ve yöntemlerinin alıcı ve ifade edici dil gelişimi üzerinde etkili olduğu dikkate alınarak özellikle ebeveynlerin diyaloğa dayalı kitap okuma konusundaki farkındalıklarının arttırılmasına yönelik çalışmalar yapılması ve bu süresinin dil gelişim düzeylerine etkilerinin araştırılması,

$\checkmark$ Anne eğitim düzeyinin ve ebeveyn mesleklerinin çocukların dil gelişimi üzerinde etkili olduğu dikkate alınarak bu farkı açıklamaya yönelik çalımalar yapılması,

$\checkmark$ Ekran kullanım süresi ve ekranın kiminle kullanıldığının çocukların alıcı ve ifade edici dil düzeyleri üzerindeki etkileri dikkate alınarak aile eğitim programları ve kamu spotlarının oluşturularak farkındalıkları arttırmaya yönelik çalışmalar yapılması,

$\checkmark$ Ekran kullanma yaşının dil gelişimi üzerindeki etkisi dikkate alınarak erken çocukluk döneminde çocukların ekran kullanımının kontrolüne yönelik aile eğitim programlarının yap1lmas1,

$\checkmark$ Farklı örneklemler üzerinde tek dil ve iki dil kullanan ebeveynlerin çocuklarının dil gelişim düzeylerinin incelenmesi,

$\checkmark$ İki dilli ve tek dilli çocuklarda erken dönemde sözel dil performansındaki farklılıklar dikkate alınarak, çocukların erken dönemde dil performansını etkileyen başka unsurların belirlenmesine yönelik çalışmalar yapılması,

$\checkmark$ Yapılacak yeni çalışmalarda erken çocukluk döneminde dil gelişimini etkileyen unsurların araştırılması,

$\checkmark$ İki dilli ailelerde ya da toplumlarda yaşayan çocukların tek dilli aile ya da toplumlarda yaşayan çocuklarla farklı değişkenler ile karşılaştırılarak dil gelişimlerinin incelenmesi,

$\checkmark$ Erken çocukluk döneminde özellikle dijital teknolojinin çocukların dil gelişimi üzerindeki etkisini incelemeye yönelik karşılaştırmalı çalışmalar yapılması,

$\checkmark$ Çocuklarda ikinci bir dil öğretilmesinde kullanılacak alternatif yöntemlerin belirlenmesine yönelik çalışmalar yapılması,

$\checkmark$ Yapılacak çalışmalarda güncel ve yeni uyarlanmış dil gelişim testlerinin kullanılması önerilir.

\section{KAYNAKÇA}

Büyüköztürk, Ş. (2014). Bilimsel Araștırma Yöntemleri. Ankara: Pegem Akademi.

Büyükbaykal, G. (2007). “Televizyonun çocuklar üzerindeki etkileri”. İstanbul Üniversitesi İletişim Fakültesi Dergisi| Istanbul University Faculty Of Communication Journal, (28): 31-44. 
Byers-Heinlein, K., Fennell, C.T., Werker, J.F. (2013). "The development of associative word learning in monolingual and bilingual infants. Bilingualism": Language And Cognition, 16(1): 198-205.

Canan, N. (2012). "Okul Öncesi Dönem Çocuklarda İki Dilliliğin Zibin Kuram Gelisimi Üzerine Etkisi”. Yüksek Lisans Tezi, Maltepe Üniversitesi, Sosyal Bilimler Enstitüsü, İstanbul.

Doğan, H. (2017). "İki Dilli Öğrencilerin Türkse Yazıl Anlatım Becerilerinin Gelistirilmesine Yönelik Bir Araştırma (Şanluurfa Örneği)". Yüksek Lisans Tezi, Gazi Üniversitesi, Eğitim Bilimleri Enstitüsü, Ankara.

Erdoğan, S., Şimşek Bekir, H., Erdoğan Aras, S. (2005). “Alt sosyoekonomik bölgelerde ana sınıfına devam eden 5-6 yaş grubundaki çocukların dil gelişim düzeylerine bazı faktörlerin etkisinin incelenmesi”. Çukurova Üniversitesi Sosyal Bilimler Enstitüsü Dergisi, 14 (1): 231-46.

Erdoğan, N.I., Şimşek, Z.C., Canbeldek, M. (2017). "Ev merkezli diyaloğa dayalı okumanın 4-5 yaş çocuklarının dil gelişimine olan etkileri”. GEFAD, 37(2): 789-809.

Kalan, Ö.G. (2010). "Medya okuryazarllğ1 ve okul öncesi çocuk: ebeveynlerin medya okuryazarllğ1 bilinci üzerine bir araştırma". İstanbul Üniversitesi İletişim Fakültesi Dergisi | Istanbul University Faculty Of Communication Journal, 1(39): 59-73.

Karaca, Y., Pekyaman, A., Güney, H. (2007). "Ebeveynlerin televizyon reklam içeriklerinin çocuklar üzerindeki etkilerini etik açıdan algılamalarına yönelik bir araştırma". Sosyal Bilimler Dergisi, 9(2): 233-50.

Karslı, Y. (2015). "Bilisssel Esneklik, İki Dillilik ve Üstbilişsel Kararlar Arasındaki Gelişimsel Bağlantılar”. Yüksek Lisans Tezi, İstanbul Üniversitesi, Sosyal Bilimler Enstitüsü, İstanbul.

Kol, S. (2011). "Erken çocuklukta bilişsel gelişim ve dil gelişimi”. Sakarya Üniversitesi Ë̆̈̆tim Fakültesi Dergisi (SUEFD), 21: 1-21.

Koşan, Y. (2015). "Okul Öncesi Eğitimin İki Dilli Cocuklarn Okula Hazır Bulunuşluklarnna Etkisinin Incelenmesi”. Yüksek Lisans Tezi, Hacettepe Üniversitesi, Eğitim Bilimleri Enstitüsü, Ankara.

Köktürk, S., Eyri, S. (2013). "Dilbilim ve göstergebilim: Ferdinand De Saussure ve göstergebilimi anlamak". SAÜ Fen-Edebiyat Dergisi, 2: 123-36.

Morris, C. (2002). Psikolojizi Anlamak. Ankara: Türk Psikologlar Derneği Yayınları ( Aktr. Canan, N. 2012).

Ping, M.T. (2014). "Group interactions in dialogic book reading activities as a language learning context in preschool". Learning, Culture And Social Interaction, 3(2): 146-58.

Sağlam, M. (2015). "Bebeklik dönemi gelişiminde işitme alg1sı". İnönü Üniversitesi Sağhk Bilimleri Dergisi, 4 (1): 26-31.

Seçer, İ. (2017). SPSS ve LISREL ile Pratik Veri Analiz̧ Analiz ve Raporlaștorma. Ankara: Anı Yayınlar1.

Şeker, P.T. (2010). "Okul Öncesi Dönemde Yabancı Dil Öğretiminin Dilsel Gelişim Alanına Katkılarmmn Incelenmesi”. Yüksek Lisans Tezi, Dokuz Eylül Üniversitesi, Eğitim Bilimleri Enstitüsü, İzmir. 
Tetik, G., Erdoğan, N.I. (2017). "Diyaloğa dayalı okumanın 48-60 aylık çocukların dil gelişimine etkisi”. Kastamonu Ë̆itim Dergisi, 25(2): 535-50.

Temiz, G. (2002). "Okulöncesi Ë̆itimin Çocuğun Dil Gelişimine Olan Etkisi”. Yüksek Lisans Tezi, Selçuk Üniversitesi, Sosyal Bilimler Enstitüsü, Konya.

Topbaş, S., Güven S. (2013). Test Of Early Languge Development-Third Edition (Teld-3), Türkşe Erken Dil Gelişim Testi (TEDIL), Kullanm Kılavuqu. Ankara: Detay Yayıncılık.

Tulu, Y. (2009). "Ana Dili Türkşe Olan ve Ana Dili Türkese Olmayan (İki Dilli) 4-7 Yaş Cocuklarn Dil Düzeylerine Etki Eden Faktörlerin İncelenmesi”. Yüksek Lisans Tezi, Selçuk Üniversitesi, Sosyal Bilimler Enstitüsü, Konya.

Tümkan, F. (2007). “Televizyondaki şiddetin çocuk üzerindeki etkisi”. KKTC Milli Eğitim Dergisi, 1: 67-88.

Url:1. Languages of the World. 14 May1s 2019 tarihinde https://www.ethnologue.com/country/tr adresinden erişildi.

Yavuzer, H. (2016). Çocuk Psikolojisi, İstanbul: Remzi Kitabevi.

Yüksel, B., Yaşar, M.C. (2010). “Acquisition of Turkish of Russian-Turkish bilingual children in early childhood". Journal Of Human Sciences, 7(1): 635-46. 